\title{
CLIMA, TÉCNICA Y PODERES. MADRID, 1561-1598
}

\author{
Alfredo Alvar EzQuerra (dir.), Elena García Guerra, Juan Carlos Zofío \\ Llorente, Teresa Prieto Palomo, Leonor Zozaya Montes ${ }^{2}$ \\ Consejo Superior de Investigaciones Científicas
}

«Todo cuanto se dilate len adoptar una resolución sobre las andas del Corpus $]$ ha de llover sobre esta Villa" [2 de julio de 1568]

\section{Resumen}

En este trabajo el Equipo de Investigación «CSIC-4704» expone los resultados del uso de los Libros de Acuerdos Municipales de Madrid en tiempos de Felipe I1, para analizar los comportamientos sociales, técnicos y políticos ante la periodicidad de las inestabilidades climáticas. Al final del estudio, se recurre alusivamente a William S. Jevons y sus teorías del comercio, en que puso de manifiesto cómo las cosechas sufrian alteraciones cíclicas, en función de la vida solar.

Palabras clave: Madrid en el siglo XVI. William Stanley Jevons. Clima y sociedad. Clima y desarrollo técnico. Fuentes para la Historia del Clima.

1. Este escrito es el resultado de un trabajo de investigación realizado por el «Equipo de Investigación CSIC 4704 », en el Consejo Superior de Investigaciones Científicas al amparo de varios proyectos de investigación financiados por la Comunidad de Madrid desde 1996 a 2000 (056P/052/1996; 06/0021/1997; 06/104/98) y que tenían como objetivo la transcripción de las Actas del Ayuntamiento de Madrid. Concluido ese trabajo, en bruto, se fueron perfeccionando los resultados hasta hoy. Se ha disfrutado de otros proyectos tales como «Identidad urbana y grupos sociales. Madrid 1550-1650» (06/0078/2000); «Madrid en la Alta Edad Moderna. Repercusiones sociales y económicas del establecimiento de la corte» (06/052/2001); «La familia en el contexto social madrileño: 1550-1650» (06/0153/2002); «Cultura y profésión en Madrid en los siglos XVI y XVII» (06/0111/2003), en los que hemos esparcido los resultados de aquellas transcripciones.

2. Han colaborado en la corrección de algunas transcripciones los licenciados Miguel Ángel Garcia SÁNCHEZ y Beatriz VALVERdE CONTRERAS, Equipo de Investigación «CSIC 4704». 


\begin{abstract}
In this paper, the research team «CSIC-4704» shows the results for the climate history by using Madrid's Municipal Acts during Philp II kingdom. Therefore they analize the social, technical and political behaviors towards the ciclical changes in weather. At last, they use William S. Jevons theories in which it's shown that harvest knew alterations produced by the solar life cycles.
\end{abstract}

Key words: Madrid in the XVIth. century. William Stanley Jevons. Weather and society, technical development and sources.

Poco, por no decir nada, es lo que se sabe del tiempo climático en Madrid en la Edad Moderna y, por concreción, en la época de Felipe II. En las páginas que siguen ofrecemos al lector un estudio dividido en tres apartados fundamentales: en primer lugar, una descripción de las situaciones, en las que, temáticamente, ordenamos los acontecimientos que afectan al tiempo en el Madrid que nos interesa. Luego, el lector podrá comprobar que la inestabilidad climática y la incertidumbre humana eran las normas con las que convivían en aquellas fechas, y más aún en esta dramática segunda mitad del XVI: ese es nuestro colofón. En tercer lugar, insertamos algunos documentos enteros que por su especificidad, el haberlos sintetizado habría quitado claridad a muchas cuestiones.

Metodológicamente, la única fuente manejada son los Libros de Acuerdos del Ayuntamiento de Madrid, esto es, las actas de las sesiones municipales. Su uso tiene ciertos inconvenientes: no se anota palabra por palabra lo discutido, dicho e incluso proferido en cada reunión (cualquiera que haya redactado un acta sabe a qué nos referimos); cuando algo ocurría, hasta que la noticia llegaba al Ayuntamiento reunido podían transcurrir unos días; también acaecía que un día no se tomaba nota de un asunto y unas reuniones más tarde se registraba una deliberación sobre el tema en cuestión que a nosotros nos parece nuevo, pero ellos ya sabían de qué iba.

Como toda fuente de información histórica, los Libros de Acuerdos tienen sus problemas. Mas, una vez leídas estas páginas, son más bien sólo «problemillas» porque la riqueza de informaciones explícitas e implícitas son innúmeras como el lector podrá comprobar.

Por otro lado, para evitar lecturas engorrosas, en vez de hacer llamadas a pie de página, ponemos entre corchetes o entre paréntesis el día de la sesión municipal. Entre corchetes, si intercalamos la data en citas directas de las actas; entre paréntesis, en otros casos.

En fin, para entender, si conseguimos hacernos entender, lo que aquí se expone, han de tenerse en cuenta tres factores fundamentales: Primero, que el establecimiento de la Corte en 1561 revolucionó el volumen demográfico de Madrid. Segundo, que de la mano de Felipe II, y desde 1563-65 en adelante, había habido una constante preocupación tanto por las replantaciones en los alrededores de los acuíferos madrileños (Prado, Manzanares, etc.) como por defender sus reservas forestales la Villa de Madrid. Tercero, que obsesionó a la Casa de Austria la preservación de El Pardo, bosque de propiedad real. Desde 1583 (por lo menos) se empieza a denunciar que, a causa del cre- 
cimiento de población, Madrid se queda sin bosques y habría que buscar otros lugares para la repoblación. Así,

«En este ayuntamiento [18-IV-1583] los sesmeros de los sesmos, lugares y Tierra de esta Villa, entraron y dieron una petición diciendo que es mucha y muy notoria la falta y esterilidad de montes que esta dicha Villa y su Tierra tiene, y la grande carestía de leña y que se espera habrá mucha mayor y que de ello ha (roto) por ser provisión tan necesaria allende de esta nuestra tierra tan desacomodada para los abrigos de los ganados en tiempo de invierno, que ha sido causa de que la cría de ganados cese, que apenas se halla quién los tenga y quiera, y que en la tierra de esta Villa y partes donde han facilidad se podrían criar montes sin ningún daño, en especial, El Quejigar o Montecillo de Navachiseas hasta las Dos Hermanas, que linda con el camino real que va al Hoyo, y con el río de esta villa, en que suplicaban a esta Villa lo mandase vedar».

Iniciemos pues, la lectura temática y descriptiva de lo que se recoge en los Libros de Acuerdos del Ayuntamiento de Madrid relativo al tiempo climático.

\section{AGUAS QUE REZUMAN DESDE EL SUBSUELO Y LA LIMPIEZA Y «POLICÍA» DE LAS CALLES ${ }^{3}$}

Un grave problema en las ciudades preindustriales era el de la limpieza de las calles. Su estado en Madrid, bien descrito por muchos viajeros extranjeros, queda claro cuando el ayuntamiento acuerda barrer las calles en verano, para que no sean un lodazal en invierno. Como dijo un viajero, «lo que se orina en verano, se bebe en invierno»:

«En este ayuntamiento (12-IX-1561; se plantea lo mismo en 25-VIII-1562) el señor teniente dijo que él ha mandado limpiar las calles y plazas de esta villa, y que él coge cada día carros para la limpiarlas, y que él lo paga de su casa hasta ahora, porque los repartimientos que hacen de los vecinos de las dichas calles se quejan y agravian de ellos. $Y$ que le parece que, añadiendo esta Villa otros 2 chirriones más para que anden limpiando las dichas calles, que se podrían remediar de manera que las calles estén limpias de aquí adelante.

El señor Corregidor mandó se vote sobre ello.

El señor Álvaro de Mena dijo que están muy sucias las calles de esta villa por estar la Corte en ella, y que 2 chirriones que hay para limpiarlas no basta, porque hasta aquí se han limpiado con carros, y si llueve y viene la cimencera [=semencera; sementera] no los hallarán a ningún precio, y que el invierno estarán las calles tan lodosas que no se podrá andar por ellas. Que le parece que se deben acrecentar otros 2 para que las dichas calles estén más limpias».

Tan llenos de basura vivían que apenas eran conscientes de su gravedad. Sólo cuando llegaban las epidemias o cuando Felipe II se quejaba al ayuntamiento de tanta porquería. En cualquier caso, es muy curioso ver cómo regatean en los gastos de la limpieza municipal:

3. Para completar los temas de limpieza de Madrid, Aragón Ramirez, Cristina y Prieto Palomo, Teresa: «La limpieza de una ciudad en la época preindustrial: Madrid (1561-1600)» en Torre de los Lujanes, (Madrid) 32 (1996), pp. 175-188. 
(12-IX-1561) «y que ahora valen los carros muy baratos que antes que venga la cemencera se tomen a costa de los vecinos, pues valen más baratos que nunca valieron, y antes que llueva se limpien, y de esta manera quedará limpia la villa y no se añadirá costa a la Villa [...] El señor Diego de Vargas [regidor] dijo que una de las cosas que más importa a la salud y ornato público de esta villa es tener las calles limpias, y que están llenas de albañales de cocinas de tan malos olores que no se puede andar por las calles sin mucho trabajo. $Y$ que ha visto limpiar algunas calles después que vino la Corte, y que desde ha 2 días como se quita la basura lo ve tornar a estar sucio como de antes, por lo cual le parece que es muy necesario que se acabe de ejecutar lo mandado por los señores del Consejo en lo que toca a los albañales».

Caos notabilísimo que abochornaba a más de un regidor:

«El señor Diego de Vargas dijo (29-XII-1561) que esta Villa está con tanta necesidad de reparos de las fuentes y pilares y caminos y la calzada de las puertas Toledana y de la Vega y las puentes y otras muchas calles de la villa que no se puede pasar por ellas, y la portezuela de El Pozacho, en que son menester gastar muchos dineros. Y es muy gran vergüenza que esté como está, especialmente estando la Corte de Su Majestad en esta villa».

Al fin, el bonancible invierno de 1563, empujaba a los regidores a tomar decisiones para empedrar las calles: «En este ayuntamiento se acordó (27-II-1563) que, por cuanto el tiempo hace muy bueno para poder empedrar las calles de esta villa, y es cosa que conviene al servicio de Su Majestad y bien de esta villa y vecinos de ella, que Ayllón, portero, y Pedro de Porras vayan, el uno, a Alcalá y Guadalajara y el otro, a Toledo, a buscar empedradores»). Pero ni el empedrado se solucionó ni el aderezo de las fuentes, esas tan necesarias «por la grande falta de agua que hay en el verano» (28-II-1565). Imaginemos los barrizales: aguas que supuran desde el subsuelo; caudales de agua mal dirigidos. La presión demográfica era una razón para el caos, pero también que como Madrid era una ciudad mediocre, no había expertos en esto de tratar las aguas: «En este ayuntamiento (22-VIII-1565) se cometió al señor Bartolomé Velázquez de la Canal para que trate con Orejón, vecino de Guadalajara, que venga a encañar el agua de las fuentes de esta villa, y se le pagará lo que con él se concertare». No debió funcionar la intervención porque «en este ayuntamiento (17-IX-1565) se cometió al señor Álvaro de Mena para que haga empedrar la cuesta de la Vega y encañar el agua a parecer de los alarifes». El 18-VIII-1567 un particular solicitaba poder aderezar la fuente de La Priora porque «[Juan Prieto] no halla firme y el agua que mana es mucha, y no le da lugar a poderlo ahondar [para hacer unos cimientos]»»

Problemas similares había a la entrada de Palacio. E1 9 de julio de 1565 el ayuntamiento se hacía eco de una cédula real por la cual «Su Majestad, parece que será servido que por la utilidad que se sigue de continuar el empedrado de la calle de San Juan, desde a donde ahora está hasta entrar en Palacio, se debe hacer una calzada. Y asimismo, empedrar la delantera de palacio, porque en tiempo de aguas no se puede pasar ni entrar en palacio, y los negociantes y todos los demás pasan trabajo». El rey estaba dispuesto a cargar con la mitad de los costes y hacerlo efectivo semanalmente; el ayuntamiento lo cargaría a sobras de rentas y, por su parte, el ayuntamiento encargaba 
el trabajo a Juan Bautista de Toledo. No obstante, el asunto era tan serio que se convocaba un pleno monográfico.

Por otro lado, también rezumaba el agua cerca del alholí de la Villa, «por la callejuela de detrás de la casa de Catalina, morisca» (18-V-1569); o en los alrededores de las Fuentes del Peral (22-VIII-1571); o en el Prado de san Jerónimo (26-X-1575).

Los problemas eran tantos que desde muy pronto el ayuntamiento empezó a abandonar algunas de sus competencias en manos de particulares: así, el mantenimiento expedito de caminos: «En este ayuntamiento [6-V-1566] se acordó que Francisco de San Martín pellejero haga el camino que ofrece por su petición por su tierra junto al vado de Aravaca a vista y parecer del señor don Pedro de Ribera y de los alarifes de esta Villa y de Alonso del Valle sesmero de pecheros de esta Villa [...] a causa de los manantiales y trampales que se hacen en él no se puede pasar a pie ni a caballo por él».

A principios de 1570, se habla de que las aguas rezuman en el Arenal y va a haber problemas para resolverlo: «En este ayuntamiento [5-IV-1570] se leyeron dos peticiones, una dada por parte de los vecinos de la calle del Arenal en que, en efecto, piden que atento a que el arroyo que cuando llueve se hace y pasa por la dicha calle hace mucho daño, se ensanche por la parte de la casa de Juan de Montes. Y otra dada por parte de Juan de Montes en que lo contradice, dando para ello algunas razones»; y no sólo el problema estaba en ese enfrentamiento sino que como dijo el regidor Nicolás Suárez en la discusión que siguió a la presentación de sendos memoriales, que «la Villa no tiene dineros y está muy empeñada [...] que esta Villa no está ahora en estado de poderlo hacer, aunque quiera». Por tanto, según Pedro de Ribera, «que los vecinos paguen una muy buena parte, que se entiende que ha de ser las dos tercias partes, conforme a cómo se suele hacer en otras calles que se aderezan» o Velázquez de la Canal y algún que otro regidor, «siempre se ha resuelto que si los vecinos quieren se corte, que ellos lo paguen». La cuestión estribaba en que los vecinos habían construido en los aledaños del arroyo y fluían las aguas hacia el cauce del Arenal, aguas que antes las empapaba el suelo porque eran tierras yermas. También habían construido en el lecho del arroyo del Arenal. Con estas dos imprudencias, se les inundaban las casas porque las aguas se represaban. Como quiera que la discusión municipal fue ardua y, en ocasiones, disparatada, porque a veces más parecen juntas de vecinos que sesiones municipales, sintetizamos exponiendo las palabras del contador Peralta, del regidor Pedro de Ribera y la resolución del Corregidor: el contador Peralta arguyó que «desde que él se acuerda, ha visto todas las vertientes que hay en la Calle Mayor y Puerta del Sol y calle de San Luis y barrio de San Martín que vienen a parar a la calle del Arenal. Y antes que esta villa creciese tanto en edificios, no hacía daño a las calles por donde pasaba, y que ahora, por razón de haberse acrecentado tanto el dicho arroyo, ha crecido en tanta manera que se entra por las casas en tanta cantidad, y es de manera que los vecinos están en mucho peligro de ahogarse y perder sus haciendas. Y que él ha visto, por vista de ojos, lo que ha entrado en las casas, y que esta Villa está en obligación de acudir al remedio de ello. Que le parece que la dicha calle se ensanche para dar lugar al dicho arroyo. Y esto se haga por la parte de Juan de Montes desde su esquina, que vaya 
bajando hasta la casa de Moradillo». En segundo lugar, una parte del parlamento de Pedro de Ribera, a quien «le parece que es cosa conveniente que esta Villa ponga remedio en ello por la vía y orden que mejor parezca, teniendo consideración a que, tanto cuanto más el pueblo se aumentare por aquella parte, tanto ha de ser mayor la avenida y daño de todo aquel barrio». Y el Corregidor zanjó todo con un explícito: «Cuando Su Majestad partió de esta villa, dejó un memorial rubricado de su mano y firmado de Martín de Gaztelu, su secretario, de las obras que se habrían de hacer, y cual primero y cual luego, y que hasta que esto se acabe que no hay que tratar en que se haga otra cosa ninguna, y que el dicho Juan de Montes labre su casa y le haga buen provecho». Dicho sea de paso: para vadear el Arenal, se echaban unas piedras que de vez en cuando había que ver cómo estaban: «En este ayuntamiento [21-XI-1578] se acordó que Antonio Sillero vea las piedras que están en el arroyo de San Ginés para pasarle cuando llueve por venir tan grande y necesario el paso, y lo haga poner de manera que aunque más grande venga se pueda pasar». Años más tarde: «Que el obrero ponga unas piedras, las que fueren necesarias, de las que están en la obrería, en el arroyo de San Ginés para el paso del agua» (19-XI-1593).

Volviendo al problema de las aguas libres dentro de la ciudad, en 1570 y concretamente, a primeros de julio en otra parte de la villa se planteaba lo mismo: «En este ayuntamiento [5-VII-1570] se cometió al señor don Pedro de Vozmediano para que haga empedrar la calle que va desde la plazuela de San Salvador al arco de Santa María y hacerla bajar y dar corriente, de suerte que quede buena por que no se puede pasar por ella en lloviendo por poco que sea ni en todo el invierno».

En 1587 sorprende un acuerdo municipal: es muy expresivo.

«En este ayuntamiento [20-IV-1587] Pedro Rodríguez de Alcántara dijo que es muy necesario que para que la gente pase por la calle del Arenal que está enfrente del hospital de Santa Catalina de los Donados por donde va el arroyo se haga una puente, atento que cuando llueve va por él tanta agua que de ninguna manera se puede pasar no embargante que están puestas piedras para ello, porque las mujeres no pueden pasar»».

Otro acuífero que rezumaba a sus anchas y se llevaba tapias y paredones de vez en cuando, era el arroyo de san Jerónimo, que fue arrastrado, por lo menos, en la primavera de 1588.

Hasta el otoño de 1576 no se ve que el ayuntamiento planee en serio empedrar las calles. Fue entonces, cuando se decidió tomar a crédito de particulares la importante suma de 500 ducados. Pero, como ocurría siempre, hubo regidores contradictores de la decisión. El Corregidor ordenó al regidor Nicolás Suárez que presentara un informe de los préstamos municipales habida cuenta que él no estaba por la labor ni de empedrar calles a esa altura del año ni pedir préstamos. Suárez se excusó, «El dicho Nicolás Suárez dijo que él está muy ocupado y enfermo y que no lo puede hacer con tanta brevedad como su merced lo manda» y el Corregidor se hartó: la reunión, que venía siendo violentísima y altanera, saltó por los aires:

«El señor corregidor dijo que el dicho Nicolás Suárez sólo tiene intento a impedir no se empiedren las calles porque decir que es tarde es notorio que si hay diligencia sobrará tiempo para las calles que hay que hay [sic] que empedrar, que son algunas tan importantes 
que no se puede andar por ellas y además de convenir al ornato público se aderecen el limpiar los hoyos y barrancos que ellas en hay y costare más que empedrarlo y en invierno no se podrá andar por ellas y para el pasar el pasar a él. Y a principio de este verano se hicieron otras proposiciones para el mismo efecto en este ayuntamiento y no hubo efecto por semejantes contradicciones y las calles que forzosamente conviene empedrarse son la Mayor, la Concepción Jerónima, parte de la de Toledo, reparar y aderezar la del Arenal, la de los Caños viejos a Santander, y que si luego con brevedad no se hace se acabaran de deshacer y desempedrar todas de manera que cueste mucho más que ahora costaba, y que los 500 que se tomaron prestados no bastan a empedrar sola una calle que el dicho Nicolás Suárez tiene habilidad y suficiencia y ha entendido en las cuentas y nadie mejor que él podrá saber y entender los alcances si los hay y es cosa y ocupación de dos horas reconocer los alcances y mandaba y mandó que Rodrigo de Cieza Alguacil mayor saque los libros y lo demás que sea necesario de poder de escribanos y contador y se lo entreguen para que mejor lo haga y se cobre para esto no es causa ni impide lo demás, pues en el entretanto se pasaría el tiempo del empedrar y en el ínterin que se empiedra, se cobrarán los alcances y de ellos se pagará»,

\section{a lo que el aludido replicó,}

«El dicho señor Suárez dijo que él nunca ha sido en que no se empiedren las calles ni se reparen como se verá por todos los acuerdos que sobre ello han pasado en este ayuntamiento estando él presente y que no ha contradicho sino el buscar dineros prestados por no saber de qué se han de pagar y que si el dicho señor corregidor tiene memoriales de las cuentas y alcances que se han hecho sus mercedes las mande ver por allí se cobrará».

El caso es que el 29-IX-1576, en otro tono, es verdad, se volvió a la necesidad de empedrar las calles, pero ahora con una novedad, el lamento de la ciudad: «está esta villa tan pobre y alcanzada que buenamente no lo puede hacer a lo menos con la brevedad que conviene por el peligro del invierno». Es cierto: desde 1561 a Madrid, Felipe Il sólo le había veniđo con exigencias y ellos sólo buscaban satisfacer al rey. El caso es que los festines por la tercera boda del monarca (1571) habían acabado por arruinar las endebles arcas municipales.

En 1580 se estaba empedrando la calle de Atocha hacia el Hospital de Antón Martín, pero los hospitaleros habían usado influencias y maniobras para paralizar el cobro que se les hacía de la parte proporcional de las mejoras. El Corregidor, desesperado, advertía a la Villa y la instaba a pleitear (12-X-1580):

»Ya Madrid sabe la buena obra que se hace en bajar y allanar y empedrar la calle de Atocha y el gran beneficio que de ella resulta a las casas y vecinos, y especialmente al Hospital de Antón Martín cuya casa estaba inhabitable si la calle no se aderezara, especialmente en invierno. Y con esta consideración se le repartió la parte del empedrado que le cupo con mucha moderación como a los demás vecinos y también a esta Villa y a los lugares de su Tierra, se le cargue el bajar la calle y lievar la tierra, que cuesta mucha suma de maravedís. Y por parte del dicho hospital se ha pretendido indebidamente libertarse de esta contribución y aunque han acudido al Consejo con muchas peticiones entendiendo que en esto tenían justicia, lo han remitido al dicho señor Corregidor. El cual por haber procedido en esta causa el señor vicario de esta villa ha proveído cierta carta con censuras para que no proceda en ella y se vuelva libremente las prendas que están sacadas al dicho hospital por el dicho empedrado. Y si a esto se diese lugar no se podría hacer [a ninguna] obra ni 
empedrado pues todas tocan en el beneficio a las iglesias, monasterios y hospitales y a sus casas y posesiones y vendría a conseguirse el beneficio a costa de los legos».

En fin, como acabamos de ver, en 21 de junio de 1581 se determinó que de la obligaduría de las velas se abonara una parte de esta obra,

«Juan Sánchez del abasto de las velas, está obligado a đar 12.000 reales de alcabala, con 1.000 reales de prometido y los 11 restantes ordenaron y acordaron que, los 2.000 reales de ellos se gasten y distribuyan en la obra del corredor que en el acuerdo antes de este se trata, y los 9.000 restantes se gasten y conviertan en continuar el empedrado de la calle y camino que va a Nuestra Señora de Atocha, desde el remate de las últimas casas hasta el pilar, atento que aquella que es calzada pública es tan precisa y necesaria y que no hay casas que sean obligadas a contribuir y se ha de gastar forzosamente, a costa de esta Villa, el dicho empedrado y no se puede excusar ni dilatar, porque al invierno esté hecho, porque si se aguardasen las aguas no se podría andar ni subir por aquella parte de esta villa y así lo proveyeron y determinaron»».

Unas semanas después, empezaron fuertes lluvias, que hicieron temer que todo se iba al traste, sobre todo lo rehecho entre el Prado y la calle de Atocha, por «las avenidas del agua no hagan el daño que han comenzado» (11-VIII-1581).

Diez años después, el problema llegaba a su cenit. Desde el 14 de febrero de 1590 en adelante, Antonio Sillero, alarife municipal, advertía gravemente, de viva voz y por escrito, de que

«las fuentes de la calle nueva están tan dañadas y estragadas que no se puede beber de ellas sin gran daño y riesgo de la salud, y podrían infeccionar el lugar, lo cual resulta de las inmundicias y suciedades que echan en el sitio donde antes estaba el pilar viejo. $Y$ el agua está tan sucia que en él hay que contaminan los materiales, y si se cegase y empedrase se remediaría este daño. Que da cuenta a esta Villa de ello para que lo mande proveer y hacer, que se remedie con brevedad y señalar de dónde se ha de pagar lo que en ello se gastare. Y que asimismo, con las aguas de las lluvias que bajan del prado de San Jerónimo se han cegado ciertos encañados y la fuente del pilar del camino de Atocha no corre y la está aderezando, que la Villa asimismo provea de dónde se ha de pagar lo que en ello se gastare»».

El ayuntamiento, que creía ciertamente en que para que las calles estuvieran transitables había que empedrarlas (otra cosa era su incapacidad de conseguirlo), determinaba que ken lo de las fuentes de la calle nueva se ciegue y terraplene el dicho sitio y empiedre». Pues bien: el 6-IX-1591 se hacía mención a «que el camino de Nuestra Señora de Atocha donde está el pilar está tan peligroso que sino se remedia con la brevedad que requiere y llueve se vendrá a llevar el pilar».

Constantemente se pueden encontrar acuerdos similares a los anteriores: la ciudad era un lodazal... y había más problemas recurrentes: «Acordóse [20-VIII-1586] que se haga un paredón de cal y canto de 4 pies de ancho en el barranco de la Calle Nueva, linde de la plazuela del Alamillo, que, a causa de las aguas, ha descarnado las casas, de manera que si no se remedia y hace, vendrán a caerse como lo están algunas».

La impotencia del hombre, en sede de la Corte de Felipe II es impresionante. En el invierno de 1563, tras las riadas del otoño de 1562, «en este ayuntamiento (4-I-1563) se cometió al señor licenciado Barrionuevo para que haga traer nueve piedras berro- 
queñas, para poner en tres partes en el arroyo del Arenal, por donde pase la gente los días que liueve»».

El establecimiento de la Corte en Madrid obligaba a un desarrollo de las infraestructuras tal, que la ciudad, incapaz de tenerlas, ni aun de mantenerlas se arruinaba día a día: antes, con que pasaran unas mulas cargadas y algún carro, se aprovisionaba la ciudad; ahora, eran carros y chirriones a diario con cuyo peso se horadaban los puentes y se venían abajo.

\section{LA MURALLA QUE SE DERRUYE}

Algunas almenas de la muralla hubo que demolerlas en otoño de 1579: «Acordóse [14-IX-1579] que se paguen a Antonio Sánchez por Luis Calderón 12 reales que gastó en derribar unas almenas en la cava que se caían con las muchas aguas». Y en diciembre de 1586 se plantea la posibilidad de derribarla entera porque se hunde, entre otras cosas, debido a que han construido galerías debajo sin apuntalarla, se llevan las piedras, etc (véase doc. adjunto).

\section{CLIMA Y SALUD}

A partir de 1581 aparecen más y más acuerdos en los que se pone en relación el tiempo climático y la salubridad. Aparte de las procesiones que se preparan para que cese la sequía «y por la salud», se ordena

«Que a costa de los gastos de pestilencia, porque conviene a la salud obviar el polvo que se levanta en las calles, especial en este tiempo de estío que tanto importa que se procure remedio para que cese, el señor corregidor y comisarios de la peste provean y den orden que las tres calles principales de Atocha y Toledo y calle Mayor y Arenal se barran y se rieguen cada segundo día con odres y azacanes o de la forma que mejor les pareciere y tomando peones que barran» (7-VII-1581).

Y es verdad que nos acordamos de Santa Bárbara cuando truena. La dura sequía y el excesivo calor del año, unido a la peste pulmonar metió prisa en los regidores para

«En este ayuntamiento [14-VII-1581] se platicó y confirió cuánto importaría que la plaza Mayor de esta villa estuviese empedrada, por lo que la experiencia ha mostrado del beneficio tan notorio que se ha seguido para la limpieza, ornato y policía y salud de haberse empedrado la plaza de San Salvador y otras plazuelas y todas las calles de esta villa por el polvo que de verano se les causa y el lodo e inmundicias de invierno y otros muchos inconvenientes que son notorios de no estar empedrada la dicha plaza Mayor, donde concurre toda la república cada día a comprar los mantenimientos necesarios, y padecen los inviernos el trabajo que se ha visto. Y para remediar esto, acordaron que la dicha plaza se empiedre por buena orden y traza, de manera que la dicha plaza quede la más llana que sea posible y con corriente bastante a todas partes. Y lo que se gastare en esta obra se reparta a esta villa y a los vecinos interesados a parecer de los señores Corregidor y San Juan de Sardaneta y don Lope Zapata, a quien se nombraron por comisarios para esta obra, por cuyas libranzas se pague lo que de ellos se gastare comunicándose con el señor licenciado Jiménez Ortíz e informándole el señor Corregidor de ello». 
Ellos sabían que algo malo pasaba en verano con los restos de los animales: no es la única vez que se toma un acuerdo similar a éste, pero el ejemplo es muy ilustrativo de qué era la ciudad:

«Acordóse [6-VII-1588] que de aquí en fin de septiembre se provea de un hombre con una bestia menor y un serón y garabato, ande por todas las calles buscando gatos y perros y otros animales muertos y los lleven fuera del lugar, en parte que no ofendan, para que se evite el gran daño que hacen a la salud, especialmente en tiempo del estío».

Cuestión esta de la prevención contra animales muertos que afectaba al sacrificio de corderos, poco aconsejable, porque se «tiene [por] experiencia que esta carne en este tiempo de caniculares está enferma y dañada de sanguiñuelo y otras enfermedades y no conviene que se mate ni venda» (1-VIII-1588).

$\mathrm{Al}$ año siguiente, todo era un poco más dramático: la peste de Barcelona había provocado que en Madrid, se levantara una cerca y se pusieran guardas contra la peste. Pero como se había hecho en pleno invierno, se había venido abajo por dos veces. Por ello, pedía Madrid que se le permitiese retirar las guardas y dejar de hacer y rehacer la cerca: que con las guardas de los puertos secos debería haber suficiente (30-X-1589).

La llegada de la peste de final de siglo, como ya ha sido analizada en otro lugar, con estas mismas fuentes, no se repetirá aquít.

\section{RESERVAS MUNICIPALES DE ALIMENTOS}

Uno de los temas más intensamente tratados por la ya perdida historiografía agrarista de hace décadas, fue el de las crisis de subsistencia. En Madrid hubo muchas. Unas fueron producto del crecimiento demográfico; otras, por problemas climáticos.

Aunque había usos de aprovisionamiento municipales, para evitar males mayores, como por ejemplo, guardar de un año para otro las reservas de paja de las reses que se iban a sacrificar y que no se había hecho por cualquier motivo ( En este ayuntamiento (16-V-1561) se acordó que Francisco Solano, mayordomo de las carnicerías de esta Villa, alquile el pajar en Amaniel, de Juan Carrero, y haga llevar a él la paja que sobró de los bueyes de las carnicerías de esta Villa para que este allí para el invierno que venđrám), lo cierto es que, como es bien sabido y no nos entretendremos en ello, lo más preocupante era mantener abastecida a la población. Para ello, la función del pósito era doble, de reserva y de préstamo. Lo vamos a ir viendo:

Las primeras noticias de carestías que tenemos para este periodo son de 1563: «En este ayuntamiento (2-VI-1563) se acordó que el mayordomo del pan del depósito de esta Villa, dé a panaderas 100 fanegas de harina, para que, luego, lo den en pan cocido en la plaza, por la necesidad que hay de pan cocido por las muchas aguas, y acudan de cada fanega con 37 panes de a 2 libras, y lo vendan a 9 maravedís cada pan de 2 libras, y lo registren ante Francisco Díaz, portero».

4. Alvar EzQuerra, A.: El nacimiento de una capital europea. Madrid entre 1561 y 1605, Madrid, 1989, pp. 64 y ss. 
Cuando había que sacar cereal para préstamo a campesinos, se pedía licencia al Consejo: es lo que pasó en 13-XI-1564: «En este ayuntamiento [...] dijeron que atento que conviene renovar cierto trigo que está añejo y a la poca cosecha que el año pasado hubo se suplique a Su Majestad sea servido de dar licencia para que se pueda dar a los labradores de esta Villa 2.000 fanegas de pan por mitad para sembran».

La sucesión de malas cosechas y sequías fue dramática desde 1575 en adelante, porque lo mismo se dieron 1.300 fanegas de trigo para sembrar (16 y 21-XI-1575), como que «acordóse [29-II-1576] que el señor don Pedro de Vozmediano hable al Ilustrísimo Presidente de Castilla para saber de él si quiere que se hagan algunas procesiones por la falta del agua para que, sabida su voluntad, se haga». Las lluvias no llegaron y en otoño de 1576 , volvieron a darse otras 1.000 fanegas de préstamo para sembradura (8-X-1576). Ahora bien, debieron arreciar las precipitaciones en otoño, porque «en este ayuntamiento [22-X-1576] el señor Corregidor dijo que está acordado que se vaya a la visita de la tierra de esta villa y él quiere, en sentando el tiempo, salir a ello y cumplir con lo que es obligado».

No obstante, en febrero de 1577 se adivinaba que la situación que se avecinaba iba a ser dramática: el Corregidor instaba a los regidores a que se movieran para conseguir, pagándoles dietas por desplazamientos, hasta 30.000 fanegas compradas donde fuera para el suministro del alholí de la Villa (4-II-1577). Además, unos meses después, ante la petición de ayuda de los ganaderos, se determinaba que, tras la siega, se dejaran los tallos sin rastrojar para que se los comiera el ganado, que no tenían otra cosa con qué alimentarse: «En este ayuntamiento [12-VI-1577] se acordó que, atento la gran falta que hay este presente año de hierba para el ganado y los sesmeros de la tierra y jurisdicción de esta Villa han dado petición en este ayuntamiento que para algún remedio del ganado convendría que ningún rastrojo de esta Villa y su tierra, después de sacado el pan, no se arrastre la paja de ellos, sino que los dejen para algún remedio del ganado. Y visto que conviene que así se haga, se acuerda que se pregone en esta Villa y su tierra, para lo cual se den mandamientos que ninguna persona pueda rastrear los dichos rastrojos hasta pasado el mes de julio primero venidero...» En 10-I-1579 los obligados de las carnicerías pedían una revisión de los precios al alza porque no había carne, «la pérdida de los obligados es mucha y muy notoria y la falta de las carnes es grande por la esterilidad de los tiempos»».

La primavera de 1578 fue tan calurosa que, además de bajar sin agua el Manzanares, al Corregidor se le instó a que suspendiera la visita a la Tierra de Madrid (26-V-1578), «el tiempo de la visita -dice un regidor al Corregidor- ha de ser cuando se pueda andar todo el día en el campo, desde la mañana hasta la noche, haciendo la dicha visita y mojonera de ella, lo cual ahora no se puede hacer por causa de la dicha calor, especialmente que ahora es el agosto en que los labradores están todos ocupados en él y la dicha visita no se puede hacer como conviene».

Los males no cesaron: «En este ayuntamiento [9-VII-1578] se acordó que desde hoy hasta postrero de diciembre de este año de setenta y ocho no se lleve alcabala alguna a ninguna persona que trajere a vender trigo, cebada, centeno y avena y harina en la casa de la harina de esta Villa y en las plazas y mercados de ello o en otras partes 
de esta dicha Villa, atenta la necesidad y falta que hay al presente en esta Villa de este mantenimiento».

Todo esto, unido a la quiebra de las rentas municipales que estaba dándose desde 1571 en adelante, debió promover a que Gregorio de Paz, mayordomo del pósito, vendiera el trigo sin respetar la tasa, por lo que se le abrió un proceso judicial. El ayuntamiento acudió en su defensa, «que, si se diese lugar a que, so color de las culpas de que es acusado el dicho Gregorio de Paz u otro cualquiera de los que han cobrado esta dicha hacienda, se procediese y determinase ninguna cosa en perjuicio de ella, sería acabar de consumir y destruir el pósito de esta villa, más de lo que él está, a causa de haberse encargado de abastecer esta villa y corte por la mucha esterilidad de los años pasados» (14-III-1581).

El caso es que el Ayuntamiento, desde 1580 no tenía libertad de decisión en lo referente al pan, que dependía de las órdenes de un Consejero de Castilla, Jiménez Ortiz (primera intervención municipal de este hombre, 19-XII-1579 ó 27-1V-1580). Pues bien, en mayo de 1581, ante las más negras previsiones, «este año que comienza desde este mes de agosto de ochenta y uno de cuya cosecha se espera poco remedio por la esterilidad del campo y por estar tan adelante», Jiménez Ortiz indicó que se hicieran con cien o ciento cincuenta mil fanegas de trigo y que las pagara la Villa con censos contraídos, «que el Consejo le daría todas las facultades necesarias» (13-V-1581).

Esa misma sequía era la que estaba a punto de matar de calor a todos en Madrid. Parece ser que se estaba haciendo un corredor para defender del sol la sala de reuniones del ayuntamiento, pero, por las fechas en que estamos, no había dinero, de tal manera que se determinó sacarlo de donde fuera (21-VI-1581):

«En este ayuntamiento se acordó que lo que está ordenado y provédo de que el corredor de este ayuntamiento se alargue y vaya continuando hasta la esquina, se cumpla y efectúe de cualesquier dineros que esta Villa tenga, y porque el tiempo es tan riguroso de calor y no se pueden hacer los ayuntamientos sin mucho daño de la salud, por no estar hecho este reparo para el sol que da en la sala, acordaron que se pida que se haga luego sin más dilación y se tome el dinero prestado de lo procedido de la sisa del vino que se hizo y echó para la guarda de la peste y en la que se echó para los gastos de la guerra para que se cumpla y pague lo que costare la dicha obra luego, entretanto que de los propios se puede proveer la cantidad que en ellos se gastare y volverse a la parte donde se hubiere tomado prestado [...]Y que el dicho señor Corregidor y comisario averigüen si de lo procedido de la parte de las penas de los montes perteneciente a esta villa hay dinero caf́do para la dicha obra lo libren desde luego en él los dichos maravedís, de manera que por ninguna causa ni razón se dilate la dicha obra».

En esa reunión se acordó que una parte de la fianza de la obligaduría de las velas se destinara a pagar esta obra y la del empedrado de Atocha, atento que «no se puede excusar ni dilatar, porque al invierno esté hecho, porque si se aguardasen las aguas no se podría andar ni subir por aquella parte de esta villa y así lo proveyeron y determinaron.»

En cualquier caso, la primera petición de aplazamiento del pago del arrendamiento de tierras por la esterilidad es de ese,verano de 1581, en que Boadilla del Monte lo hace, «atento que por la esterilidad del tiempo no han cogido grano» (19-VII-1581). 
En ese orden de cosas debe recordarse que el Presidente de Hacienda echa balones fuera y responde en Cortes que si todo está perdido, no es por cuestiones de encabezamiento, sino «que, aunque se entendía que el estado de las necesidades que el Reino representaba no procedía del encabezamiento, como decía, sino de la esterilidad de los tiempos» (en acuerdos municipales, 20-IX-1581).

En marzo de 1582 se inspeccionaban todos los molinos de Madrid y sus alrededores (Jarama, Henares, etc.) para ver si molían o no y por qué causas (13-III-1582), porque había que aprovisionarse de harina (10.000 fanegas) por si acaso (24-IV-1582).

Poco durarían las vacas gordas, porque en agosto se fueron a La Mancha a comprar cien mil fanegas de trigo, difíciles de conseguir porque la sequía tocaba a todos. El caso es que, además, el comisionado de Madrid, Nicolás Suárez, era hombre de edad y su salud preocupaba a los compañeros de ayuntamiento, por el «rigor y carestía del tiempo» (3-VIII-1582).

El caso es que en agosto de 1582 se abrió un periodo de malas cosechas, cuyos efectos se intentaron paliar con embargos en La Mancha (primeros de agosto de 1582)... y su suspensión en julio de 1583 , ante las perspectivas de excelente cosechas, que se confirman, porque a la altura de 1587 el Corregidor reconoce los tres buenos años atrás, lo cual le hace sospechar que habrá malas cosechas pronto. No obstante, estará bien comprar 200.000 fanegas al muy bajo precio que estarán y rehacer el alholí (20-V-1587). El tema vuelve a tratarse en junio, con el beneplácito de los regidores ( 15 y 19 de junio) que instan a una reedificación del alholí (24-VII-1587). El Consejo Real no autorizó semejante compra, con los perjuicios que se causaron al catastrófico año siguiente.

Y llegó 1590. Aunque a principios de año se creía que iba a haber excelente cosecha, la decepción llegó antes de la siega; en junio se empezaban a preparar rogativas y «la cosecha del pan de este presente año no están buena como se esperaba generalmente hablando» y se opta comprar como se suele en los años de «mediana cosecha» (20-VII-1590).

En la primavera de 1593, la Junta actuó: se firmó un asiento con Antonio Grafión para que él se encargara del abastecimiento de trigo de Madrid. La respuesta del ayuntamiento no fue unánime, naturalmente. La experiencia había mostrado a unos que los regidores ya no estaban para ocuparse también del cómo dar de comer a sus convecinos, y que lo que había que hacer era entregar a una contrata, a una especie de obligaduría la provisión. Otros, por el contrario, preferían que las cosas siguieran como hasta entonces, a pesar de ser un ayuntamiento completamente desbordado y que tenía que tratar con Juntas y Alcaldes de Casa y Corte...

\section{PROCESIONES Y ROGATIVAS}

De las primeras veces que se habla sobre hacer rogativas suplicantes por agua, fue en abril de 1581. En efecto, por esas fechas se platicaba sobre la conveniencia de empezar a hacer procesiones por «necesidad que al presente hay de agua y la falta que 
hace cada día» (17-IV-1581). Así, en efecto, se organizó una procesión general (acuerdo de 19-IV-1581):

«En este ayuntamiento se acordó que mañana a las 7 de la mañana se haga procesión general y salgan de Santa María para la iglesia de San Sebastián de rogativa por la salud general del Reino y de esta villa y por los buenos temporales. Y para que haya efecto, el señor Pedro Rodríguez de Alcántara convide a las órdenes y el señor Marcos de Vega, la clerecía, y el señor don Lope Zapata hable al vicario para que lo ordene y mande así y que el mayordomo haga llevar los bancos de la cárcel y haga asientos donde esté esta villa en la misa y se le notifique. $Y$ que se le notifique a todos los señores regidores de esta villa no falten a la dicha procesión con pena de dos ducados aplicados para los pobres de la cárcel».

Había pavor a la sequía, sí; pero también al catarro, a esa tremenda peste pulmonar que atacó la ciudad en esas fechas... y a Castilla entera.

Se debió hacer, en efecto, la procesión y debieron prometer a los santos protectores mil y una recompensas, pero como siempre, algo chapuceramente: para esa, u otra procesión rogando por salud y agua, se había traído a Madrid la imagen de Nuestra Señora de Valverde. Se le puso un vestido muy grande pero taumatúrgico, que era el de la Virgen de Atocha (a la que se lo había comprado el ayuntamiento de Madrid el 19 de septiembre de 1580 para agradecerle que hubiera intercedido por la salud de Felipe II; el vestido sería «de saya y manto de tela de oro carmesí»); sin embargo, la imagen de Valverde que probablemente no había visto ningún regidor de Madrid, pero sí habrían oído sobre sus capacidades, era demasiado pequeña para el vestido que le imponían (¡qué disparate, qué estampa, qué rogativa!), así que pasados los males, se decidía ayudar con 12.000 maravedíes para la obra de la ermita que se empezaba a hacer para la de Valverde y se devolvía a la Virgen de Atocha el vestido con un regalo adicional de 8.000 maravedíes, suponemos que para que no se enfadara por habérselo quitado para una intercesión mejor (29-XI-1581). Así que, una virgen de fuera mal vestida, la local, desnudada, todas abochornadas o enfadadas y para zanjar tanta desorganización, recompensas económicas en la certeza de que así quedaría equilibrada la codicia de las intercesoras.

El problema de las lluvias y los aguaceros volvió a plantearse en el mes de enero de 1582. Entonces, aquel ayuntamiento de $<<$ religiosos paganizados $>>$, como nos atreveríamos a llamarlos, decidió cambiar de santos protectores. De momento, contra san Sebastián sólo se atrevieron modificando el itinerario de una rogativa (19-I-1582): «atento las grandes lluvias y lodos que hay y mal tiempo que hace que se solía ir a San Sebastián con la procesión, se acuerda que se vaya a Santiago con la procesión».

En estos años iniciales de la década de los 80 vemos cómo hay alguna inquietud con respecto a los santos protectores. Parece ser que la Virgen de Valverde logra que llueva cuando se le saca en procesión; como viene de fuera, acuden a recibirla a las puertas de la ciudad los propios regidores: «Acordóse [27-IV-1584] que para el martes, que viene la imagen de Nuestra Señora de Valverde, por el agua, la Villa salga a recibirla con 12 hachas blancas, las cuales lleven los caballeros regidores que a ello fueren». 
Comoquiera que durante los cinco años siguientes hubo excelentes cosechas, los creyentes se olvidaron de la Virgen. Hasta tal punto que, cuando empezaron los males de nuevo, se recurrió a otros nuevos santos: icon tantos cambios, no se podía proteger bien de la sequía!

En la primavera de 1589 (10-IV-1589) «se acordó que se dé una petición en el Consejo Real representando la necesidad que parece que hay de agua y suplicando se mande dar como se hagan rogativas públicas, las que se acostumbran en semejante necesidad y por carta se diga y suplique lo mismo al señor cardenal de Toledo, nuestro prelado») y unos días después se insistía con más claridad (17-IV-1589):

«Especialmente 3 en que esta villa ha de ir y hallarse: la primera mañana martes, al colegio de las Niñas Huérfanas, donde se diga una misa delante de la Santa imagen de Nuestra Señora de Loreto, a las 8 horas de la mañana; y el jueves al monasterio de la Merced, y la misa se diga delante de la santa imagen de Nuestra Señora de los Remedios, y el sábado a Nuestra Señora de Atocha, todas a una hora».

Se hizo la procesión en primero de junio de 1589 , pero con pocos resultados, porque en julio andaban las cosas igual de secas (5-VII-1589). Empezó a planear el fantasma del hambre: el 1 se septiembre se dio trigo al monasterio de Atocha, como solía hacerse en estas circunstancias.

A primeros de junio de 1590, aunque el invierno había sido bonancible, se empezaban a preparar procesiones otra vez (8-VI-1590).

Bien podemos sospechar que el ambiente en las procesiones era más bien festivo, o jocoso, que de preocupación:

«Acordóse [1-VII-1592] que se ejecuten los acuerdos que esta Villa tiene hechos antes de ahora para que en las ventanas de la Villa en tiempos de fiestas estén con su antigüedad y no se siente nadie en lugar de otro y estén con mucha compostura con sus capas y espadas y en las procesiones generales y otras votivas que esta Villa acude, por la Villa, los señores regidores vengan a este ayuntamiento para que de él salgan por su antigüedad con el señor Corregidor para ir a las partes donde se hubiere dicho».

E incluso a veces o con absentismos o no tan lucido como debería ser:

[30-I-1595] «Que los porteros del ayuntamiento asistan en ir a las procesiones de la Villa, a cada lado seis, y no falte ninguno so pena de un ducado. Y se les dé a cada uno una vela de a 3 en libra».

Sea lo que fuera, en la primavera de 1593 (5-V-1593) se empezaban a preparar procesiones para el sábado 8 de mayo y otras más sonadas los días 11 y 14 (véase el proceso completo en Apéndice). Ahora bien: esta procesión fue única en su especie porque durante la misma, hubo una conversión de un musulmán en cristiano $\mathrm{y}$, tras ella, la solicitud de rescate. Milagrosa procesión, sin duda. Por cierto, que puestos a ver señales, la ayuda municipal al rescate del cautivo se tomó en el (todavía aún no) Día de la Hispanidad:

«Acordóse que [12-X-1594], atento que Juan de Atocha se tornó cristiano cuando la bendita imagen de Nuestra Señora de Atocha salió en procesión por la rogativa del agua el año pasado de noventa y tres y esta Villa fue su padrino y ahora se ha significado que se 
quiere rescatar y está concertado el rescate en 800 reales con su amo y le ha pedido a esta Villa ayude para ello. La Villa acordó que se den para ayuda al dicho rescate 300 reales de propios, dando licencia para ello los señores del Consejo».

Pero la sequía continuó y se prolongó a 1594: en la primavera, nuevamente, empezaron los protocolos para hacer las rogativas (desde 25-IV-1594). Pero eran años de novedades: ahora el cambio radicaba en la veneración a Nuestra Señora de Loreto, y la caída en desgracia de la de Valverde; y el triunfo de la una sobre la otra no implicaba el olvido de, por ejemplo, san Sebastián:

«En este ayuntamiento [2-V-1594] se acordó que, atento la necesidad que hay de agua para los temporales por estar el tiempo tan adelante que se dilata y es bien que se suplique a Nuestro Señor se sirva de darla como es menester para los temporales, haciendo procesiones y oraciones por ello y que, atento que esta Villa tiene licencia del señor Presidente del Real Consejo para gastar lo necesario en ellas, se acuerda que se haga el jueves por la tarde una procesión general que salga de Nuestra Señora de Loreto, trayéndola desde su Santa Casa a la iglesia de Santa María de esta villa y venga por la calle de Atocha derecha y entre por la iglesia de San Sebastián y allí se haga oración y baje por la Plaza y Platería a la dicha iglesia y donde esté tres días y los señores comisarios de la cera del Santísimo Sacramento provean de la que fuere necesaria, así de hachas como de velas, para que se alumbre la dicha Santa Imagen...», etc.

A partir de ese verano, también, empezaron las rogativas bajo la protección de san Roque (12-VIII-1594). No obstante, en enero había que celebrar a san Sebastián (18-I$1595)$, en abril a san Marcos (24-X-1595).

Curados a trancas y barrancas los males de aquella sequía, en 1598 se volvió por los mismos derroteros. Quien dio el visto bueno a una procesión de primavera de 1598 fue el propio rey:

[2-V-1598] «Su Majestad está mejor esta tarde gracias a Dios y ha sabido que se trataba de sacar mañana a Nuestra Señora de Atocha por el agua, y dice que le parece bien que sea por todo y vuestra señoría dé orden cómo la villa pague lo que se suele gastar en aquel día. Nuestro Señor guarde vuestra señoría. En Palacio, a 2 de mayo de 1598, don Cristóbal, al licenciado Rodrigo Vázquez Arce, Presidente del Consejo Real.

Por tanto que la villa de orden como luego se ponga en ejecución que Su Majestad manda se haga y se provea todo lo que fuera necesario para este efecto, y visto y entendido por la villa a-se avise al padre prior de Nuestra Señora de Atocha y se le dé noticia de ello para que esté prevenido, y se traiga la bendita imagen mañana domingo en la tarde, y venga por la calle de Atocha y por la plaza y Puerta de Guadalajara y calle de Santiago, y por las casas de don Pedro de Ludeña y de allí derecho a Palacio y de allí a santa María y se lleve la bendita y margen a la dicha iglesia, y se ponga en lugar muy decente donde esté el tiempo que pareciere y se ordenare, y los señores Juan Fernández y Sebastián Hurtado tengan cuidado de la capilla mayor y la iglesia y donde está la bendita imagen para traerla. Se lleve el ¿palio rico? de esta villa y doce hachas blancas, que las traigan 12 frailes del monasterio, y llegada a santa María estén alumbrando la bendita imagen 6 hachas en los seis hacheros que esta villa tiene plateados, y dos velas blancas de a libra cuarto en el altar mayor y ocho alumbrando la bendita imagen, y el señor Matute lo haga hacer, y las hachetas necesarias que traigan los señores regidores alumbrando la imagen, con lo cual queden seis religiosos 
el tiempo que estuvieren en la iglesia, a los cuales se les dé de comer y coman lo necesario por orden del señor Juan Fernández «, etc.

Una semana después el ayuntamiento decidía que, por haber llovido, regalaría a la imagen de la Virgen de Atocha una corona de oro y a su Hijo, otra (8-V-1598).

Con el regalo a la Virgen y con la muerte del rey en 1598, despedimos este apartado.

\section{EL FUEGO, SUS DESMANES Y OTROS ELEMENTOS DE DEFENSA}

El fuego, y sobre todo tras la dramática experiencia de Valladolid, se convierte en una obsesión. Pero conviene tener presentes dos cosas: no preocupan los incendios extramuros, los forestales y, en segundo lugar, se depende de Toledo. La dependencia con respecto a Toledo, pone a las claras cómo los regidores madrileños, recién instalada la Corte, se saben segundones frente a la ciudad Imperial. Tal vez si no hubiera Corte en Madrid, y un Corregidor de fuera de la Villa, acaso no se preocuparan por los incendios. Los encargados de ocuparse de estas cosas son carpinteros: «En este ayuntamiento [20-VIII-1561] el señor corregidor dijo que ya sus mercedes saben los fuegos que acaecen a esta villa y que de no haber aparejo para atajarlo acaecen grandes desastres, que se vote sobre lo que se debe hacer sobre ello, porque será bien que de Toledo y otras partes se prevengan de aguatochos y otros instrumentos y garfios para atajar los fuegos, pues en todas las ciudades y villas de todo el reino de buen gobierno lo hay, pues es justo que estando Su Majestad y su Corte en esta villa lo haya, pues se gasta en otras cosas de menos provecho».

Instalada la Corte, empezaron inmediatamente edificaciones de tan poca calidad, como aún es notorio de intuir en Madrid por su trazado urbano. En fin, en 17-XII-1561 se decide preparar ordenanzas para todos los que tienen que ver con la construcción, y una de las partes de los exámenes tiene que ver con los incendios: «En este ayuntamiento se cometió al señor Diego de Vargas para que haga las ordenanzas de los exámenes de albañilería y carpintería y yesería y tapiadores, y para los remedios de los fuegos y reparo de ellos, cuando en las casas acaecen y para los herreros y cerrajeros y chapuceros y caldereros. Y se dé orden en las dichas ordenanzas como las obras que hicieren de aquí adelante sean perfectas y bien hechas, porque de no haber las dichas ordenanzas se siguen gran desorden y gran perjuicio a la república». Claro que de poco sirve tener las ordenanzas si no se imprimen o si no se hacen las herramientas al uso, en ellas contenidas. ¿Los costes?, se suplirán con cargo a los beneficios de poda y provisión de leña, como es lógico: «que se hagan las herramientas contenidas en las ordenanzas para el remedio del reparo del fuego, que son herradas de clavo y jeringas y hachas de pico y martillo y garabatos y escaleras. Y lo que costare lo pague Alonso de Paz del dinero de la leña) (17-XII-1561). El ayuntamiento aprobó las ordenanzas el 28-II-1562 y las remitió al Consejo Real.

Pues bien, el 16 de mayo de 1567 Madrid «se concertó con Alonso Toledano, herrero, vecino de esta villa, que hará 12 hachas, martillos en aceradas las bocas y 
martillos, por un ducado cada una, para en tiempo que hubiere fuegos en esta Villa, las cuales hará conforme a una hacha que trajo por muestra».

El verano de 1564 fue muy seco y se quemó una parte del monte de Vallecas (la noticia, el 15-IV-1565). En la primavera siguiente, como ya rebrotara, se prohibió la entrada de ganado cabruno.

Ya hemos visto que toda la ciudad tenía en 1567, doce hachas municipales para defenderse contra el fuego. Pues bien, las campanas eran otro útil importante. Lo que pasa es que por viejas, no repicaban como deberían: «En este ayuntamiento [16-VI1567] entró el cura de San Pedro e hizo saber como la campana de San Pedro está tan quebrada que no suena ninguna cosa. Y porque parece que para los nublados conviene que se torne a hacer, que Su Señoría vea si se tornará a hacer o no. Y visto por los dichos señores, les pareció que se ha de hacer»».

\section{PUENTES... Y VADOS}

Desde el establecimiento de la Corte, uno de los problemas más graves con los que se enfrentó la Villa de Madrid fue el de sus comunicaciones con el exterior. No nos vamos a ocupar de puertas, barcas o puentes más que en lo relativo a las repercusiones que el clima tiene en esas construcciones... o al menos eso es lo que vamos a intentar. Además, desde 8-X-1563 en que Felipe II decide intervenir en el urbanismo de Madrid $^{5}$, el ayuntamiento pierde muchas de sus competencias, sobre todo ha de pedir licencia para hacer pagos de obras que no sean con cargo a sus propios, de tal manera que si la ciudad tiene que reparar, empedrar, aderezar, limpiar, reconstruir, las arcas municipales no dan a basto y hay que solicitar socorro o licencia al rey para poner sisas o cambiar las partidas de pago. Y si el rey niega, el puente se viene abajo. Y esto es lo que pasó. No obstante, bueno es empezar en los orígenes de este marasmo, esto es, desde 1561

\section{La puente Segoviana}

El puente más importante de Madrid era el de Segovia. Lo era, no por su trajín económico, escaso, sino por ser el acceso palaciego hacia los lugares de recreo regio. Por ello, mientras que el de Toledo fue de madera y una pesadilla, o desde Valencia se entraba a Madrid por unas barcazas que día sí, día no, andaban hundidas o sin amarres, y se atravesaba el inseguro puente de piedra de Viveros, a la Casa de Campo se accedía desde 1565 por un puente como Dios manda. Veamos el proceso de construcción.

En la primavera de 1563 había saltado la alarma en la salida hacia el noroeste de la ciudad, «en este ayuntamiento se acordó (20-III-1563) que, por cuanto se ha dicho que

5. Como se ve, desde poco después de establecerse la Corte, hay cierto interés desde la Corona por adecentar Madrid. Un poco más adelante, se elevó un memorial al rey que trataba sobre las necesidades urbanísticas de Madrid (entre 1564, 1565). Ese memorial lo descubrió Javier Rivera (Juan Bautista de Toledo y Felipe II, Valladolid, 1984. Sobre el particular véase ALVAR EzQUERRA, A.: El nacimiento de una capilal europea..., pp. 192 y ss. 
la puente Segoviana se ha empezado a hundir por los ojos de en medio, que se repare a parecer de los alarifes». Claro que como todo era urgente y no había materiales, se expropió temporalmente una «casilla» y, más aún, se levantó el pavimento de una calle para aderezar el puente: «En este ayuntamiento se acordó (3-IV-1563) que se tome la casilla de Francisco de Madrid, que está de la otra parte de la puente, para meter pertrechos que son menester para aderezar la Puente Segoviana y se le pague el tiempo que estuviere ocupada [y] se acordó que, de la piedra que se ha sacado en la calle de San Juan, se lleve a la Puente Segoviana, lo que pareciere a los alarifes que es menester y lo demás». En 2-VII-1563 se fue a visitar las obras y en 4-VIII-1563 se daban por terminadas ya que se hacen libramientos de pagos.

No obstante, no se debieron hacer a conciencia porque «en este ayuntamiento se cometió (6-XII-1563) a los señores Corregidor y Diego de Vargas para que aderecen la puente Segoviana lo que se ha llevado el río, con parecer de los alarifes». Tal fue el descalabro que a los pocos días hubo una intensa reunión municipal en la que se entremezclaban clima, arquitectura y... finanzas municipales:

«En este ayuntamiento (29-XII-1563) se platicó acerca del daño que las crecientes pasadas hicieron en la puente de Segovia, en que derribó obra de 500 pies de largo de la dicha puente hacia la otra parte del río, que es cerca del olivar. Y tratado y conferido de dónde se podría aderezar en presencia de Pedro de Herrera y Alonso de Zárate, hacedores de rentas, y de Juan Simón, diputado de los tratantes y contribuyentes en las dichas rentas, que para ello fueron llamados, dijeron que el reparo de la dicha puente es necesario que se haga por cuanto no se puede pasar carro y meter bastimentos en esta dicha Villa, que se debe aderezar y reparar de sobras de encabezamiento, atento que el beneficio y reparo es necesario, útil y provechoso a esta Villa y tierra. Y luego los dichos señores justicia y regidores acordaron que se repare la dicha puente de sobras de encabezamiento; y se comete al señor Diego de Vargas, como está cometido, para que, juntamente con el señor Corregidor, se haga aderezar, y libren lo que costare en Marcos de Almonacid para que lo pague de las dichas sobras. Y lo firmaron de sus nombres los dichos hacedores y diputado de rentas, en 10 de enero de 1564 años»

El 20-XI-1564 se les ocurría empedrar la cuesta que bajaba al puente, por la puerta de la Vega, y encañar un golpe de agua que deterioraba todo (probablemente fuera un qanate o una arca cambija que rebosara agua)...

Pero, el 3-I-1565 se reconocía que el río había hecho unos hoyos en el Puente de Segovia y que había que repararlo.

En fin, el 2-III-1565 se adoptaba la decisión de que el Corregidor y dos regidores fueran a visitar al licenciado Espinosa, del Consejo de Castilla, para hablar con él «sobre lo de las puentes Toledana y Segoviana». La reunión tuvo lugar el 18-V-1565. El licenciado Espinosa les preguntó que qué lugareños eran los que más usaban el puente de Toledo (que debió ser el centro de la reunión). Madrid respondía que daría un memorial sobre la cuestión, pero que no tenía propios con qué sufragar los gastos de mantenimiento, por lo que solicitaba que se hicieran derramas a 20 leguas enrededor del puente, esto es, a poco más de 110 kilómetros. El caso es que el 14-IV-1565 se daba orden de reparar, otra vez, un agujero que se había hecho en el puente... Por fin, en 7V-1565 el ayuntamiento de Madrid decidía solicitar al Consejo Real licencia e instruc- 
ciones para aderezar los puentes de Viveros, Toledo y Segovia. Como se puede ver en Apéndice, el 8-VI-1565 el rey daba una provisión por la que mandaba la reparación del puente de Toledo. Se iniciaba una nueva fase de la historia de esa pesadilla; sueño que debió durar bastante, porque el pulso de las reuniones municipales es el mismo en el otoño: «Acordaron [15-X-1565] que vista la necesidad que hay para adobar las puentes Toledana y Segoviana antes que entre más el invierno, que se manda que se adoben...». Desde entonces, la salida del alcázar de Madrid hacia el cazadero de la Casa de CampoEl Pardo, tendría un puente de piedra, mientras que las demás salidas...

Ahora bien, las lluvias de febrero de 1575 dañaron la puente Segoviana: «En este ayuntamiento se acordó [9-II-1575] que se repare el puente Segoviana del reparo de que tuviere necesidad y del daño que ha hecho en ella las crecientes del río».

Hasta 1590, parece ser, no hubo necesidad de nuevos reparos (19-[-1590). Debieron ser importantes porque se habla de «la quiebra que nuevamente ${ }^{6}$ se ha hecho en la puente Segoviana» (30-I-1590).

En fin, la falta de cuidados provocó en 1593 la inquietud porque «habiendo tenido noticia la Villa que la puente Segoviana, siendo obra tan principal y necesaria, se va enarenando, se acordó que el señor Gregorio de Paz hable al señor licenciado Guardiola, comisario de la dicha puente, para que su merced mande que se remedie» (3-XI-1593). Hasta dos años más tarde no hay nuevas noticias de la necesidad de «reparos» (11-III-1595), aunque sin mucha capacidad de ejecución porque en 4-VIII-1595 se sigue hablando que el puente se enarena:

«Acordóse [4-VIII-1595] que los señores Corregidor y Gregorio de Usátegui y don Luis de Toledo vean qué remedio se puede dar para que se desembarace la puente segoviana nueva porque cada día se va enarenando más y mostrando mayor el daño».

\section{La Puente Toledana}

Ya en la primavera del año siguiente al establecimiento de la Corte, se avisaba de que

«En este ayuntamiento se acordó [11-V-1562] que se dé petición en Consejo para que la puente Toledana, que está caída y para se hundir toda, y el reparo de ella es grande y conviene que se haga de manera que se pueda pasar por ella, así con carros como con coches, porque de hacerse de esta manera cesarán los inconvenientes de ahogarse personas, como sean ahogado el invierno pasado y otros años pasados, por no poder pasar por la puente con carros y coches》).

En junio (3-VI-1562) se mandaba a dos regidores a exponer al rey «sobre el aderezo de la puente Toledana y sobre otros pasos y puentes malos que hay, para que se aderecen». Habría que esperar un poco, hasta el otoño (9-X-1562) cuando los maestros que fueron a verle anunciaban que la Puente Toledana, inspeccionada por orden de Felipe II, «se ha de derribar, y sobre las cepas de ella, haciéndose más anchas, se torne a hacer más ancha, y que es obra larga. Y para que en el entretanto que se hace, hay

6. Nttevamente siempre quiere decir «de nuevas» y no «de nuevo». 
necesidad que un poco que está caído en la dicha puente se repare». En el otoño de 1563 se hacían los trabajos de manera un tanto chapucera:

«Y en cuanto a lo que toca al aderezo de la puente Toledana dijeron (los regidores, 8-X1563) que para hacerse la dicha obra como conviene de una de dos maneras: o haciéndose de nuevo, conforme a la traza y condiciones que para ello están dada o haciéndose derruyendo, conforme al parecer de los alarifes que está en poder del señor licenciado Espinosa, del Consejo de Su Majestad, ni para lo uno ni para lo otro ya no es tiempo porque para hacerse es obra de grande y es menester comenzarla al principio del verano. Por tanto, que les parece que para ahora se debe aderezar lo que está caído de la dicha puente Toledana para que se pueda pasar por allí este invierno a pie y a caballo que costará poco y que al verano se podría tratar de una de las dos maneras arriba dichas, pero les parece que lo que más convendría y sería mejor sería hacerse de nuevo, conforme a la traza y condiciones para que puedan pasar carros perpetuamente por ella sin perjuicio de la dicha puente y que lo que es menester para el reparo de ahora se traerá el mes prescrito, habiéndolo visto el domingo antes»,

y en 8-X-1563 se visitaba el puente con el Corregidor y con el Presidente de Castilla. Vistas las reparaciones, unos días después se reanudaban las obras, y que «se pague lo que costare, lo cual se libre en la persona que el señor licenciado Espinosa mandare» (10-XI-1563). A principios de enero de 1565 había recibido daños; a mediados (15-I-1565) ya se ordenaba pagar la reparación de los desperfectos, lo que «costó echar tierra en la puente Toledana para allanar lo que se llevó el río».

Hasta marzo de 1568 no «se acordó [18-III-1568] que se aderece la puente Toledana muy bien al parecer de los alarifes y se aderece luego de manera que quede muy buena»s.

$\mathrm{Si}$ aquel aderezo fue bien hecho, explicaría el silencio en las Actas municipales hasta febrero de 1590, en que hubo que aderezarla de nuevo, como la Segoviana, o las barcas de alrededor de Madrid (7-II-1590). En los meses siguientes continúan las dispersas informaciones que nos hablan de trabajos en el puente, ordenándose que se hagan los reparos necesarios (30-IV-1590). No obstante, la intromisión real en estos asuntos por la creación de la Junta, provoca la implícita reacción municipal. En agosto de 1590 le dicen al rey que si quiere que el puente esté bien, como ha creado una Junta, que lo haga él:

«En este ayuntamiento se acordó [1-VIII-1590] que los señores comisarios [representantes de Madrid] de la Junta de las obras propongan en ella el estado en que está la puente Toledana y la necesidad que tiene de reparos, y lo que se entiende que costará y cómo Su Majestad ha mandado que se sustente y cuán imposibilitados están los propios para poderlo hacer, procurando que en nombre de la dicha Junta se informe a Su Majestad de todo ello y se le suplique mande dar facultad para que en la dicha Junta hagan reparar la dicha puente y repartir a los interesados lo que fuere necesario para ella...»>

Es más que probable que el pulso lo perdiera el Ayuntamiento, porque en septiembre se nombró al regidor don Luis de Toledo como comisario «del reparo de la puente Toledana» y se le instaba a que en compañía de dos alarifes, "con toda diligencia se haga reparar para que este invierno presente pueda pasar por ella con bestias y gente suelta». 
Pero, además, el Ayuntamiento que ya estaba arruinado, decidía el mismo día también que si hubiera algún particular que se comprometiera a mantener el puente en pie, que se le entregara una suerte de obligaduría:

«Si hubiere persona que se obligue y dé fianzas de reparar la puente Toledana y tenerla en pie por un año cumplido de la forma que el señor corregidor y el señor Diego López de Ribadeneira dieren. Los dichos señores lo hagan efectuar y hagan que se repare y aderece luego» (7-IX-1590 para las dos citas).

El particular apareció y se firmó el acuerdo ante el escribano Juan del Hierro Barrionuevo: el carpintero Juan de Herrera se comprometía a mantener el puente en pie a cambio de 3.000 reales pagaderos de los propios, excepto 200 ducados en préstamo que aportaba otro particular, avalados por el Ayuntamiento con unos solares de Atocha (31-X-1590).

Ahora bien, el carpintero se encargaba del puente. No de lo de alrededor: en el verano de 1591 (17-VII-1591) hubo que abonar 98.922 maravedíes por «el reparo que se ha hecho en la presa que está junto a la puente Toledana por donde pasan los carros con bastimentos». Los carros más pesados, en fin, no pasaban por el puente: ya nos los había dibujado décadas atrás Wyngaerde. No obstante, en enero de 1592 un regidor, Diego de Urbina, protestó ese pago y esa reparación porque no se había hecho con acuerdo municipal... y es que parece ser que el comisario de las reparaciones, don Luis de Toledo, había actuado demasiado libremente, o deprisa (22-I-1592). Se organizó una buena, y los regidores asumieron que «que, atento que la dicha obra fue tan útil y tan necesaria como está dicho y que, si el señor don Luis no tuvo comisión tan cumplida como convenía para hacerla, debió entender la tenía, y se ocupó con buena fe en ella y por este defecto no es justo que él ni otra persona alguna laste por la buena obra y beneficio que la república recibió, y así, si es necesario, suplen dicho efecto y aprueban la dicha obra y el haber acordado que se pague, con que lo que se pagare sea con la justificación y moderación que se hacen»..., etc.?

El caso es que la entrega a obligaduría y todo lo demás no sirvió para nada. Los costes de mantenimiento eran de tal porte y las reparaciones tan endebles, que se pidió al rey licencia para derribar el puente y que todo el trajín entrara a Madrid por el puente de Segovia. El rey, sin embargo, se negó a ello. Madrid hubo de plantearse entonces levantar un puente en toda regla, pero sufragado por todas las localidades que lo aprovecharan. Corría el año de 1593.

«Acordóse [20-VIII-1593] que, atento que la puente Toledana está tan mal reparada que no se puede pasar por ella a pie ni a caballo ni en otra manera, de que redundan muchos inconvenientes, y habiéndose suplicado a Su Majestad fuese servido de mandar que aque-

7. Don Luis de Toledo era hombre de Corte. Señor de Villafranca del Castillo (en las inmediaciones de Madrid, se yerguen los restos de la fortaleza, en medio de un encinar y justo enfrente de una estación de seguimiento aeroespacial, en un paisaje de película), había entrado en el Ayuntamiento por renuncia en él de Gaspar Prado y era yerno del Aposentador Mayor de Diego de Espinosa, Comendador del Campo de Criptana, etc.). Guerrero MAYllo, A.: El Gobierno Municipal de Madrid (1561-1606), Madrid, 1993. p. 284 . 
lla puente se derribase y que todo el paso fuese por la puente Segoviana, no fue servido de ello, sino que se quedase la dicha puente, y que este reparo es muy forzoso si la dicha puente ha de quedar. Los señores don Luis de Toledo y don İñigo de Mendoza, con el señor Corregidor, con maestros y oficiales vean la dicha puente y los reparos que son menester hacerse para que quede reparada para siempre y qué costará y se dé petición en Consejo, haciéndose relación de este acuerdo, pidiendo licencia para que se reparta el dicho gasto entre todas las ciudades, villas y lugares del contorno que contribuyen y han contribuido para la dicha puente Segoviana, atento que esta Villa no tiene propios de donde poder hacer el dicho reparo, porque será muy grande el gastor).

Mientras tanto, se habían hecho aderezos cerca. La calle que bajaba al puente por fin pudo empedrarse en 1592, pero, al parecer, malamente, «la calle de Toledo se ha empedrado ahora nuevamente y ha quedado mucha tierra en ella y si entra más el invierno y las aguas de él echarán a perder el dicho empedrado» (12-X-1592).

Mientras tanto, también, se seguían haciendo las reparaciones como se tenía acordado (1-IX-1593), pero con unas arcas municipales vacías, lo cual provocaba facturaciones del tenor siguiente: «Que los 24 reales que Fernando Méndez gastó en poner unos maderos en la puente Toledana, atento que eran necesarios, y los ponga en gastos de pleitos» (27-IX-1593); «que Gregorio Sánchez reciba el dinero que se acordó que se tome prestado del colegio de los Niños de la Doctrina para pagar de presente lo que esta Villa ha de pagar para el reparo de la puente Toledana» (15-XII-1593). Y es que el Consejo Real presionaba para mantener el puente en pie. En fin, en 1594 se volvían a pagar reparaciones desde bienes de propios (23-V-1594). Todo esto muestra que la ciudad estaba hundiéndose en sí misma y en sus necesidades. De nuevo, en junio de 1594 ,

"Que el señor Gregorio de Usátegui hable al señor presidente sobre que se repare como convenga la puente Toledana, atento la mucha necesidad que hay de ello por ser el paso tan ordinario y $\tan$ necesario» $(30-\mathrm{VI}-1594)$

El 16-XII-1594 se volvió a reunir en sesión extraordinaria el Ayuntamiento para pedir al rey licencia para la reparación final del puente de Toledo, «atento que está muy mala, que no se puede pasar por ella los caminantes y trajineros que vienen y traen bastimentos a esta villa». Y el 13-I-1595 se acordaba, lacónicamente, «que se aderece el paso de la puente Toledana, porque no se puede pasar por algunos malos pasos» (idem 24-I-1595). Nuevamente el 4-VIII-1595 se volvía a solicitar el auxilio de la Junta y/o del rey:

«Que los señores Gregorio de Usátegui y Diego de Chaves Bañuelos hablen al señor Presidente de Castilla sobre lo de la puente Toledana, suplicándole mande que en la Junta se trate de que se haga una puente nueva, atento el daño que tiene la vieja que está ahora y le representen los inconvenientes que resultan y pueden resultar de que se esté la dicha puente vieja».

Cerca del puente debía formarse una presa de aguas que, según la Villa, la provocaba el molino del «doctor Sánchez» y ella no consideraba que debiera pagar el saneamiento de la zona, por lo que, ante la escasez de dinero, decidió pleitear contra el dueño del molino, «esta Villa no está obligada a reparar y adefezar la presa que está 
junta a la puente Toledana, por pertenecer este aderezo al molino del doctor Sánchez» (18-VIII-1595).

En septiembre de 1595 sigue todo igual, aunque se es explícito: tras los reparos, que se venda la madera vieja para poder costearlos (4-IX-1595). Hay aún más alusiones a aderezos de este tipo (20-XI-1595, 20-XII-1595 ...).

En fin, en 1598 se hizo una derrama en la ciudad para pagar las reparaciones, siendo uno de los soportes de ese arreglo, el dinero dado por los Niños de la Doctrina...

Así, pues, vemos como la Naturaleza, unida a la quiebra de la fiscalidad municipal, provocan la aparición de los particulares en el apuntalamiento de los bienes municipales. Propios, ayudas externas (obligadurías, socorro regio, préstamos) y derrama entre los vecinos son las tres fases para paliar esta angustia que sólo tenía una solución: la técnica. Esto es, construir un buen puente de piedra. Pero el rey fue el responsable de este lastre al no autorizarlo o al no sufragarlo. $Y$ es que los costes eran muchos y variados, como para preocuparse de cómo entraban en Madrid los chirriones de La Mancha.

\section{La Puente de Viveros y la Barca sobre el Jarama}

Fuera de la ciudad, en el camino de Valencia, se denunció que el puente de Viveros se venía abajo por la presión del agua. Es un texto que, en el fondo acabará sonando a cantinela:

«Diego de Carrera dijo que ya les es notorio cómo ha años que la puente de Viveros está peligrosa y al punto de que si no se pone remedio en ella con brevedad, se hundirá toda. Y que ahora al presente, que habrá tres dias pasó por ella, y vio que de los pies derechos y cepas de ella, de lo nuevamente edificado, se han caído algunos sillares y quedan en vago las cepas, y de causa de no poner breve el remedio con toda brevedad se hundirá la puente por estar el daño principal en la más corriente y furia del agua, y lo otro, por faltar los pavimentos que estaban hechos y los por hacer y haberlos roto el agua».

A día 22-X-1563 se seguía afirmando que «porque la puente de Viveros está maltratada y menester reparo, que se de petición en el Consejo Real de Su Majestad sobre ello» para ver cómo autorizaba la financiación de las obras.

Claro que tampoco está de menos la derrota que trasluce la reunión del verano de 1564. En esta ocasión, «en este ayuntamiento (12-VII-1564) habiéndose entendido el gran peligro que está la puente de Viveros y que si no se repara este verano se caerá y, atento que no hay sobras de encabezamiento, ni la Villa tiene propios...», etc. En enero de 1565 una crecida del río, se lo había llevado por delante.

Tras el plan urbanístico de 1563 , podría parecer que el tema iba a quedar resuelto. Nada más alejado de la realidad: en 5-I-1565 se comunicaba al «diputado de tratantes y contribuyentes» que el río Jarama se había llevado tres ojos del puente y que como no había dinero en las arcas municipales, que se les proponía tocar las sobras de rentas del encabezamiento. Tanto ellos, como los regidores, aceptaron el préstamo para la obra desde esa partida presupuestaria. El 8-I-1565 ya se iban a visitar los desperfectos; la inspección realizada por el regidor Alonso de Zárate duró dos días, aunque se le pagaron dietas por cuatro, ya que aprovechando la visita, echó un ojo a cómo iba la corta 
en la Dehesa Nueva (19-I-1565). Sin embargo, el 30 de julio de 1565 aún no se habían reparado los ojos del puente, «conviene que la puente de Viveros se repare y hagan los arcos que se llevó el río el invierno pasado». Se encargó de ello Rodrigo Gil, que determinó que la mejor reparación sería desmontándolo y volviendo a construirlo: «En este ayuntamiento se cometió (19-IX-1565) al señor Diego de Vargas para que haga sacar la piedra de la puente de Viveros de los arcos que se hundieron, para que se tornen a hacer los dichos arcos conforme al parecer de Rodrigo Gil». Pues bien, el 8 de julio de 1566 se organizó una salida municipal para ver cómo se podía actuar, porque parecía que todo estaba paralizado:

«En este ayuntamiento se acordó que con el señor corregidor vayan los señores Diego de Vargas y don Pedro de Ribera, regidores, y Juan de Villafuerte y Luis Sillero y Ribero, cantero, y Gregorio Méndez, procurador, e Isla, cantero, y yo, el presente escribano, a la puente de Viveros para ver la obra que se ha de hacer de la dicha puente y se lleve la traza y parecer que dejó hecha Rodrigo Gil, y el mayordomo de los propios vaya a dar de comer)s.

El 19 de julio se ordenaba otra visita. El 16 de septiembre se pagaban dietas a otro regidor que había ido a Vaciamadrid para ver por dónde se podía desviar el río, o «hacer una tajada para que el río no coma las tierras de Vaciamadrid». El 20 de septiembre se seguía con aquel infumable gran plan, «[que vayan algunos regidores] a la puente de Viveros a ver lo que es menester deshacer de las cepas y arcos que se lievó el río el año pasado». El 18 de abril de 1567 se pagaron dietas al alarife de la villa, Luis Sillero, que fue a inspeccionar las obras de Viveros, y se encontró con que iban a buen ritmo, con algún impedimento en el aseo de los «fundamentos» (9-V-1567). Entonces se debió decidir que estaría bien adornar los arcos del puente y se procedió a una derrama. Pero como tantas y tantas veces, todo iba con lentitud desesperante. Esta vez los nervios los perdía el regidor don Pedro de Ribera,

«En este ayuntamiento [20-VI-1567] el señor don Pedro de Ribera dijo que ya es notorio cómo ha tanto tiempo que los ojos de la puente de Viveros están llevados, y para el adorno de ellos se ha repartido el dinero que ha parecido necesario para los haber de aderezar y cobrado, por donde no resta, sino poner manos en la obra. Y habiendo como ha dos años que se llevaron, no se ha puesto piedra en ellos, siendo como han sido los años secos y muy dispuestos para ello, especialmente este otoño se podría comenzar y entibar la dicha puente para que la primera creciente que venga no se la lleve, porque si esto fuese, es muy notorio los grandes daños y gastos que a la Villa y Tierra se seguirían, que no se levantaría la dicha puente con 100.000 ducados. Por tanto, que pedía y pidió al señor corregidor y señores regidores de este ilustre Ayuntamiento, y si necesario es requiere dos y tres veces y las que de derecho se requiere, manden luego poner con toda diligencia y cuidado, como cosa de tan grande importancia, diligencia en la dicha obra para que se haga, y lo contrario haciendo, protestaba y protestó lo que en tal caso protestar le convenía, y pidiólo por testimonios?.

La sesión municipal se caldeó hasta el punto que todos los regidores apoyaron al denunciante contra el Corregidor por su pasividad, pero uno de los comisionados para la reparación del puente se levantó y se quejó: que en la derrama no habían pagado todos, que había pleitos, que la Villa no había nombrado juez ejecutor de cobranzas, 
que los pueblos de alrededor no pagaban y que él dimitía, «que él [Diego de Vargas] ha de ir fuera de esta villa y ha de estar fuera de ella muchos días. Que pide que se nombre otro comisario en su lugar, porque él desde luego se desiste de la dicha comisión». Naturalmente no se le aceptó la dimisión y se acordó convocar otra reunión para seguir tratando el asunto. El 23 de julio de 1567, Luis Sillero, el alarife municipal, informó de cómo iban las obras; el 30 de julio se nombró a un sobrestante, con 6 reales de salario, que fue muy contestado, pero que hubo que aceptarse porque al ayuntamiento se le azuzaba a que «la dicha obra de la puente de Viveros se comience con toda la furia posible»; pero ¿no se estaban emitiendo informes de cómo iban los trabajos? El 1 de agosto, por si todo lo anterior estaba aclarado, «En este ayuntamiento [1-VIII-1567] el señor licenciado de la Canal [regidor] dijo que requería y requirió a este ayuntamiento que con toda brevedad se empiece y acabe la obra de la puente de Viveros, porque se acaba el tiempo en que se puede hacer y entrando el invierno no se podrá hacer, y está en peligro de llevarse el río la puente. Que pide compelan a los comisarios de la dicha obra que lo hagan luego hacer, donde no, que protesta que sea a su culpa y cargo, de los dichos señores comisarios y no suya»y los regidores en un acto de colectiva exaltación, volvieron a usar palabras que nos son conocidas, «[que la obra de la puente de Viveros] que se prosiga con toda furia la obra», aunque, eso sí, "que envíen a ella sobrestante con el menos salario que ser pudiere». El 11 de agosto se repite el acuerdo municipal; el 13 se libran dineros y se paga una dieta de desplazamiento; el 27-VIII-1567 se mandó al alarife «desde mañana jueves a la puente de Viveros, y lleve los maestros y canteros que fueren menester para la dicha obra, y no venga de ella sin licencia de los comisarios de la dicha puente, porque conviene que, con toda diligencia y brevedad, se haga por los inconvenientes que podrían suceder»....! Y lo que podría suceder, sucedió: «En este ayuntamiento [10 - XII-1567] se acordó que Luis Sillero envíe a su hijo a la puente de Viveros a aderezar los agujeros que están en la dicha puente, y lleve para ello la madera que fuere menester». El padre, estaba a la vez aderezando «lo que se ha llevado el río de Jarama en los aportaderos de la barca de Vaciamadrid»; de nuevo se la llevó el río en 14-V-1568; los barqueros se siguen lamentando en 10-XII-1568: «en este ayuntamiento [7-V-1568] se acordó que la tajada del río de Arganda se aderece porque parece que el río la ha empezado a robar y que Luis Sillero la vaya a aderezar, y que la aderece la tajada por encima con céspedes y con lo que más convenga». En efecto, el río se acabó llevando el fondeadero de la barca de Arganda (14-V-1568), que se pudo arreglar y se pagaron los costes en 17-VIII-1569, etc.

Mientras se acababa la puente de piedra de Viveros el trajín se había ido resolviendo con un puente de madera provisional que era, ahora, el que se había llevado el río: así que en diciembre de 1567, dañados los amarres de la barca de Arganda en el Jarama y tocado el puente de Viveros, Madrid podría sufrir gravemente un revés en sus tratos con Levante: «que vayan a la puente de Viveros [17-XII-1567] a ver la puente de madera si hay necesidad de algún reparo que se haya de hacer en ella y lleve madera menuda y clavazón para los agujeros que hay en el suelo» (el 29-III-1569 se advirtió que la madera estaba «desbaratada»). El caso es que en 31-V-1568 se pagaban ciertas carretadas de piedra (hay más acuerdos similares a este; pero valga el botón de mues- 
tra). Y es que, la perplejidad o el aburrimiento privaba cualquier lector: «Luis Sillero, alarife de esta Villa, dijo [6-XII-1568] que en el destajo del abrir de la cepa de la puente de Viveros, los destajeros no cumplen como están obligados».

Pues bien: parece ser que Rodrigo Gil estaba algo desentendido de la cuestión. Entonces (22-III-1569), un maestro de cantería vecino de Alcalá de Henares, Nicolás de Ribero, solicitó hacerse con la obra comprometiéndose a terminarla en el menor plazo. Los regidores, eficaces, se enzarzaron en una ardua discusión en la que estuvieron a punto de sacar a pregón público las condiciones de la obra. Finalmente, se impusieron los que apoyaba a Ribero, en el cual se remató la susodicha obra.

En julio de ese año, el ayuntamiento decide levantar un puente en el río de la ciudad y concluir el de Viveros (16-IX-1569). El caso es que en 16-IX-1569 se acordaba sacar en almoneda los despojos de la madera del puente provisional «que esta Villa hizo en el entretanto que se ha hecho de piedra, por cuanto ya está hecha la dicha puente».

Inmediatamente (28-IX-1569) se acordaba inspeccionar los pertrechos necesarios para arreglar el puente de Toledo.

Sin embargo, unos años después, volvieron las calamidades: creció el Jarama y se llevó por delante, otra vez, la ribera: «En este ayuntamiento [13-II-1572] se cometió al señor Diego de Vargas haga reparar la tajada de la barca de Vaciamadrid, que ahora se ha llevado el río y la han visto Luis Sillero y Juan Luis, alarifes de esta Villa». Volvió a pasar lo mismo en marzo de 1574 (9-III-1574) y en otoño, una nueva crecida estropeó el puente de Viveros: «En este ayuntamiento [16-IX-1574] el señor Francisco de Herencia dijo que con la avenida que vino por el río de Jarama el viernes pasado, tres de este mes, le han dicho que se descubrieron tres o cuatro arcas de las que se empedraron en la puente de Viveros y que es necesario que se reparen y aderecen».

Posiblemente los aderezos se hicieron bien porque aguantaron unos lustros. Por ello, lo más frágil era lo técnicamente menos resistente: la barca de Arganda.

En efecto, en el otoño de 1579 volvió a bajar crecido el Jarama y se llevó la tajada de la barca:

«En este ayuntamiento [13-XI-1579], por haberse entendido del pasado de la creciente que ha venido por el río de Jarama este mes de noviembre, se había llevado un pedazo de la tajada que esta Villa había hecho por encima de la barca de Vaciamadrid, se mandó a Antonio Sánchez, que es el que la había reparado, fuese a ver el daño que había hecho la dicha creciente en la dicha tajada. El cual entró hoy en este ayuntamiento y dijo que él fue aver la dicha tajada y que el daño que el río hizo en ella fue que, como obra de 25 pies de largo hundió por la parte de abajo en este mismo largo, las estacas y piedra y reparo que allí se había hecho, hundiéndolo en la misma parte donde estaba, sin llevárselo, y quedó hecho un boquerón por haberla bajado y estar más bajo que lo otro, y este será necesario se repare luego con toda brevedad antes que venga otra creciente porque se llevará toda la tajada, y que costará este reparo como 20.000 maravedís, poco más o menos».

En 1581 tras una durísima sequía, llegaron las tormentas y en octubre el Jarama se había llevado la barca de Arganda (16-X-1581). Al acabar el verano de 1583, al fin se planteó la posibilidad de desviar el cauce del río, para tener a resguardo la barca: al ayuntamiento se comunicaba el 31 de agosto de 1583 que dos regidores y un técnico 
había ido «a ver el reparo que sería necesario hacerse para que el río se guiase por parte donde no hiciese daño en el soto de El Porcal, y la barca pudiese andar en todo tiempo por parte donde nunca faltase pasaje»; acompañaba a la notificación un informe de qué se podría hacer.

Y tal vez algo se hizo, porque en 3 de enero de 1586 se ordenaba inspeccionar los daños que «el río de Jarama ha hecho daño en la tajada vieja»..., en la vieja, y por tanto deduzco que hay otra nueva. Ahora bien, todo sin prisa: en 3-VIII-1587 sigue confiriéndose sobre la necesidad de la reconstrucción de la tajada. Cuando, es posible que, se hayan puesto manos a la obra, vienen las lluvias y hay que paralizar el trabajo (23-IX-1587).

En enero de 1590 hubo que hacer reparos de nuevo, que se prolongaron en febrero (9, 12-II-1590). Al parecer debían estar hechos los arreglos en abril de ese año y costaron 1.622 reales (30-IV-1590). El 9 de mayo de 1590, el rey había decidido llegarse a Arganda. Por ello mandaba el aderezo de los caminos desde Atocha a Vaciamadrid, pero en el Ayuntamiento se veía difícil que pudiera llegar. Así que le proponían dar un rodeo por San Martín, y el rey contestaba: que arreglaran la barca. El tema se desarrolló así más o menos: «[[Como están las] barcas imposibles en tan breve tiempo y muy peligrosas llevando el río tanta furia, despachó un correo a Su Majestad suplicándole por carta para el dicho Conde de Chinchón no pasase por las dichas barcas sino por la puente de San Martín de la Vega, y se le respondió que no podía ser porque iba a Arganda...» Ó́da con claridad la cuestión, los regidores acordaron no sólo arreglar las barcas, sino ir a Vaciamadrid a besar las manos a Su Majestad.

$\mathrm{Al}$ año siguiente hubo que arreglar nuevamente la tajada de la barca de Vaciamadrid (19-VIII-1591).

Unos años después, en la primavera de 1593 (12-III-1593) el río volvió a llevarse la tajada de Arganda y hubo que visitarla y repararla (3-IV-1593). En el otoño de 1593 le tocó a todas las barcas, a la de Madrid, a la de Arganda y a la de Vaciamadrid (6$\mathrm{X}-1593$ ). En noviembre se miraba a ver si se podía amarrar en refugio (24-XI-1593); en julio de 1594 se ordenaba visitar la tajada y ver qué reparo se podía hacer (27-VII1594; en términos similares 14-IX-1594, 20-IX-1594, ) y, en fin, la impotencia de estas situaciones se ve allá en el otoño de 1594, al reconocerse que la barca acaso no flote todo lo que debiera:

[14-X-1594] «Que el señor don Pedro de Vozmediano [es un regidor] envíe a llamar un hombre de Vaciamadrid que se encargue de la barca y la quite del río antes que crezca, porque no se la lleven las aguas».

En ese sentido, a finales de noviembre de 1594, aprovechando una visita a la barca de Arganda, se visitó también la tajada de Vaciamadrid para ver si había «algunos reparos fáciles» (25-XI-1594).

Acaso los reparos fáciles o no se pudieron hacer, o no llegaron porque,

«Acordóse [24-J-1595] que el señor don Diego de Olivares, con el procurador general, vaya a Vaciamadrid y vea en qué sitio se podrá poner la barca que estaba en Vaciamadrid, para 
que no cese el paso en derecho que allí se suele llevar y haga vender la madera de la barca vieja de Arrebatacardos. Y trate de que vaya otra persona al vado de Arrebatacardos».

Dramáticos años, estos de 1590 que afectaron a las barcas y a la puente de piedra de Viveros. El 19-X-1590 se registraba la noticia de que se había «caído un pedazo de ella y cuan necesario es el remedio de ella por ser de tanta importancia y paso tan general». Poca resistencia en estos años finales del siglo, porque en 1592 hubo que pagar otras reparaciones (30-X-1592). De nuevo hubo que hacer reparaciones dos años después (30-VI-1594), pero no anduvieron finos, porque se cayó un cuchillo del puente ( I-VIII-1594), que se ordenó su rápida reconstrucción, pagándose de los fondos que determinara el Consejo (26-VIII-1594; 7-IX-1594). Un año después, había que volver a inspeccionar el puente (3-VII-1595) y se decidía pedir licencia para repararlo bien, cobrando por repartimiento a los pueblos vecinos y hasta tanto se recibiera autorización o el dinero, que se cargaran los costes a la sisa (28-VIII-1595 y 13-IX-1595). El rey aceptó el cargo contra la sisa y se procedió a la reparación (15-IX-1595; en esa sesión se copia el poder). Al fin, en 6 de julio de 1598 se volvía a hacer alguna reparación ( $\mathrm{y}$ 8 y 15 -VII-1598) y el 26-VIII-1598, «Que se vaya continuando el reparo de la puente de viveros que se hace por orden de esta villa»...,

\section{Otras salidas de la ciudad}

El 24-III-1565 el rey ordenaba a Madrid que en ciertos lugares (Las Rozas, Majadahonda, Aravaca...) que están en el camino a El Escorial hubiera bastimentos y que «asimismo, hagan aderezar los malos pasos que hay desde esta villa a los dichos lugares» ... Y aunque no se cite, verdaderamente, la causa de la orden, es evidente: de Madrid al monasterio en construcción las comunicaciones eran dificilísimas. La reacción municipal fue rápida: mandar aderezar las vías hacia Aravaca, Pozuelo, Húmera, Majadahonda...

Por cierto: el pontón a Pozuelo volvió a retocarse en 12 de enero de 1569. Una semana más tarde se pedía ayuda al rey para el aderezo de todos los caminos alrededor de Madrid, fundamentalmente pidiendo al rey que permitiera agilidad en las decisiones municipales. El rey, habiendo visto el destartale de los regidores, había prohibido que actuaran en Madrid sin consultar a sus arquitectos. «En este ayuntamiento [19-I-1569] se acordó que se dé petición en el Consejo Real de Su Majestad, dando noticia de cuán malos están los caminos para que se dé licencia a esta Villa para que pueda hacer calzadas, esto atento que estaba por provisión de Su Majestad que no se empiece obra sin dar noticia de ello en el Consejo».

Hasta 1580 parece ser que no se acometió una salida directa y digna por el oeste de la ciudad, hacia E1 Pardo. Así, el comisionado sobre el aderezo de esa salida rendía en primavera sus primeros informes «acerca del reparo que se ha de hacer en el arroyo que sale de la Casa de Campo a la puerta principal y más adelante en el Camino de Aravaca porque hay muy malos pasos en el uno y en el otro y grandes pantanos») (22IV-1580). 
En varias ocasiones vemos que los caminos se reparan cuando se va a mover el rey (10-III-1590, 3-XII-1590, 12-XI-1590, 23-X-1591, 18-XI-1591, 17-II-1593, 3 y 19-III-1594, 30-IV-1593, 5-XI-1593, 6-V-1594, 30-X-1594, 14-III-1595, 14-VII-1595, 27-XI-1595, 10-I-1596), siempre con cargo a los propios municipales: adviértase que esa relación corresponde a las salidas hacia El Pardo, al recreo regio. Aún más, hubo que hacer (10-XI-1593) «una puentezuela que se ha de hacer junto al bosque de $\mathrm{Su}$ Majestad, atento que es muy necesaria para el paso de la gente, de a pie y a caballo». Veamos un acuerdo municipal que sintetiza lo que he dicho:

«En este ayuntamiento [3-III-1594] el señor don Rodrigo del Águila dijo que Su Majestad ha enviado mandar se repare un pedazo de camino que está junto a la Casa de Campo, que está de suerte que no se puede pasar por él. Que lo dice a la Villa para que lo haga hacer y reparar. Y visto por la Villa, acordó que se repare el dicho camino y el señor Diego de Henao lo haga hacer todo lo necesario de manera que quede bien reparado. Y lo que en ello se gastare, se pague de propios por su libranza y del dicho señor Corregidor y se gaste en esto la piedra que se echó de la puente Vieja»

Ocurría igual cuando el rey quería ir a otros sitios (Torrejón de Ardoz, 27-XI1592), o cuando el que salía era el Príncipe. En cierta ocasión, se tuvo que volver a Madrid. Iba hacia El Pardo y...

«Que el señor don Diego de Olivares vea el camino de El Pardo que va por la Casa del Campo a la parte de arriba y por Casa Nueva y lo haga aderezar de forma que se pueda pasar por ellos, atento que de parte del príncipe, nuestro señor, se envió mandar al señor Corregidor lo hiciese aderezar, porque yendo Su Alteza fuera, ayer viernes, 10 de este mes, no había podido pasar por ello...» (11-II-1595).

En 1587 eran los vecinos de Brunete los que pedían ayuda para hacer un puente sobre el Guadarrama (22-V-1587), que aún tardaría más de un lustro en levantarse. Y parece ser que, cuando todo estaba listo, hubo alguna contradicción:

«En este ayuntamiento [22-I-1592] el señor [regidor] Andrés Méndez de Jibaja propuso y dijo que la puente que está mandada hacer en el río de Guadarrama a pedimento de esta Villa y del concejo de la Mesta, que el señor conde Chinchón y lugares de su estado, aunque es muy útil y necesaria, no conviene que se haga en la parte y sitio que está señalado, que es en el vado de la barranca de Brunete, sino al vado de la Junquera, que llaman los de Brunete vado de las Carretas. Que antes que se haga yerro en la dicha fábrica, la Villa suplique al Consejo lo mande mudar y remediar y, visto por la Villa, acordó que el dicho señor Andrés Méndez trate y comunique con el dicho señor conde y con quien más le pareciere de los interesados dónde conviene que se haga la dicha fábrica»

En octubre de 1585 se decidía pedir permiso al Consejo para acometer reformas en el camino que iba a Getafe, «atento los malos pasos que hay y que de camino no se puede en invierno andar por ello» (25-X-1585).

\section{Presas y estacadas}

La importancia de Madrid puede verse en algunos conflictos con los lugares de su alrededor. Por ejemplo, los enfrentamientos por las estacadas y presas que hacían 
algunos pueblos que, naturalmente, aún no encontraban en la Villa la ciudad fuerte que sería más tarde.

Con el fin de aprovechar el curso de algunos ríos existía la costumbre de levantar pequeñas presas, con la natural reprobación por los ribereños de más abajo, «en este ayuntamiento [8-[-1561] se hizo relación que los vecinos de Arganda han hecho cierta estacada en tierra de Madrid, en el río de Jarama, de que viene mucho daño y perjuicio. Cometióse al señor Álvaro de Mena para que solicite al procurador de la Villa que haga información sobre ello para que se remedie con justicia, y salga a la causa con parecer de los letrados de la Villa). El 18-VI-1561 (se vuelve a instar sobre ello el 4-VIII1561) se decide suplicar el amparo del Consejo Real porque con esos desvíos, «viene gran daño y perjuicio para las moliendas» y es que actuaban sobre los ríos Jarama, Guadarrama y Calatalifa. También los del Real de Manzanares, enemigos litigantes desde siglos atrás por límites municipales, eran otros que actuaban con perfidia contra Madrid. Al fin, el 22-VIII-1561 (y 27-VIII-1561) se comisiona a un regidor para «hacer que se suelte el agua y venga libremente por los rios de esta villa». El problema de las sacadas de agua para moliendas se mantiene vivo en 13-III-1563, 20-III-1563. El de las estacadas que sujetan las aguas se repite en 27-X-1564 («que se quite antes que vengan las avenidas de invierno»). En 18-III-1568 vuelven por sus fueros los de Paracuellos que han hecho una presa en Fuentelfresno, término de propios de Madrid: el 7-II- 1569 se pagaban 1.600 mrs. de dietas por dos días que estuvieron el Corregidor y otros regidores visitando la Tierra de Madrid y derribando esa presa. La cuestión, era bien sencilla: sin agua remansada y soltada, no se podía moler. Ya lo iban a conocer bien en Madrid, porque años después ocurriría lo contrario: ante la continuada sequía, el Manzanares no tenía caudal suficiente para mover las muelas de los molinos de Madrid, por lo que se llevaba el trigo al Jarama (9-V-1578).

Claro que, cuando le apetecía a la Villa, no pasaba nada. En 7-IX-1562 se planteó hacer ciertas estacadas en el río Jarama para que aguantase las crecidas que se esperaban y que no se llevara el soto de la Sopeña. Para ello se contaría con la ayuda de Vaciamadrid en la esperanza de que «echen alguna piedra para que la obra sea perpetua».

En ocasiones lo que pasaba era lo contrario: ante la pertinaz sequía, se planificaban cambios de cursos de los ríos: «En este ayuntamiento [16-VI-1567] se acordó que se vaya a ver y nivelar de las partes y lugares de donde se podrá traer agua al río de esta villa, que es de Jarama y de los arroyos de Guadalix y Porquerizas y Peñalara y el río del Pavear».

\section{A GUISA DE COLOFÓN}

Desde luego que los datos aquí presentados no gozarían del efusivo aplauso metodológico de William Stanley Jevons ni de muchos modelizadores actuales. Pero esto es lo que hay: precisamente, las fuentes que maneja el historiador adolecen de ciertos reparos cuantitativos, por su propia calidad; pero las reacciones del hombre son, afortunadamente imprevisibles, por el libre albedrío, producto de la inteligencia (y no del instinto), que es la que, en último término, hace que se pueda cambiar de santo si el anterior no ha protegido bien. Buscar, buscar. 
En sus teorías sobre el ciclo económico (1875-1878), y tras sesudos análisis estadísticos, Jevons había llegado a la conclusión de que, aproximadamente cada 10'5 años tenían lugar explosiones solares que alteraban las cosechas en la Tierra y, tras ello, el «ciclo del comercio» (business circle). A él le habria encantado saber -o tal vez no, pero qué le vamos a hacer, si no se lo puedo preguntar-que en Madrid hubo alguna «picadura» de peste (o miedos a que llegaran de fuera) en 1564, 1581 y 1598, o sea, cíclicamente, cada 17 años. Acaso, también le habría encantado saber que había ciclos de buenas y malas cosechas que se intercalaban: Aunque esos ciclos ni fueron mecánicos, ni perfectos.

\begin{tabular}{|l|l|}
\hline $\begin{array}{l}\text { «Malas cosechas» } \\
\text { (término que aplicamos con imprecisión) }\end{array}$ & «Buenas cosechas» (idem) \\
\hline $1560,61,62,63$ y 64 & \\
\hline & $1565,66,67,68$ y 69 \\
\hline 1570 & (sin seguridad, 1571) 1572,73 y 74 \\
\hline $1575,76,77$ y 78 & \\
\hline & $1579,80,81,82$ y 83 \\
\hline 1584 & \\
\hline & $1585,86,87$ y 88 \\
\hline $1589,90,91,92,93$ y 94 & \\
\hline & 1595 y ss. \\
\hline
\end{tabular}

Jevons con sus teorías conseguía dar un paso adelante de capital importancia en la concepción de las economías agrarias: no es el azar el que provoca la crisis, sino fuerzas, en efecto, sobrenaturales.

Si no dejamos al azar, como creo que no debemos hacerlo, la aparición de alteraciones del clima regularmente, podremos entender mejor lo que ocurre aquí abajo, por culpa de allá arriba. En efecto, cuando la racional mente humana no es capaz de comprender por qué se «despierta» la yersinia pestis, por qué hay mutaciones, acaso tenga que plantearse que sus conocimientos son, todavia, muy pequeños para la inmensidad de lo que nos afecta. Y si una mutación vírica es de dificil comprensión, lo mismo puede ocurrir a otros seres vivos, que cambian sus comportamientos repentina y temporalmente, bien sean langostas o cereales.

Vendida todavía la soberbia o la curiosidad humanas a la escasez de sus conocimientos en este lento caminar para entender las bases de la vida, sólo ha encontrado una manera de paliar los desmanes de la Naturaleza. Y esto lo ha hecho, también lentamente, por medio del desarrollo técnico.

En las páginas de este trabajo se ha podido ver cómo una alteración del tiempo climático puede llegar a provocar una hambruna, pero si ésta no llega, habrá sido porque 
el Hombre ha podido frenar la devastación de sus efectos: buenos transportes, buenos almacenes, buena organización, nada de corrupción...

En este siglo XVI estamos en época de transiciones. El caso de Madrid es un buen ejemplo. Si hay dinero, hay técnica; si no, no. Así es que el rey baja a El Pardo por un puente de piedra, mientras que la ciudad es un lodazal o los accesos se hacen sobre puentes de madera. Si los puentes de la ciudad hubieran sido, como deseaban sus regidores, de piedra, y en vez de barcazas para cruzar los ríos hubiera habido técnica bastante (y no anécdotas técnicas) para poner largos y resistentes puentes de piedra, el abastecimiento a la ciudad siempre habría sido dinámico y no habría habido que estar malgastando dinero una y otra vez en reparaciones insufribles.

Habitualmente se hacen rebuscadas y extrañas interpretaciones de las relaciones de poder del pasado, con lo sencillo que resulta comprenderlo en función de una idea: quien controla la técnica, controla a los hombres. A Felipe II, el feliz «rey ecologista», poco o nada le interesaba la salubridad de Madrid o su buen abastecimiento salvo para evitar desórdenes públicos. Pero eso sí, exigía ornato y policía. Por su parte, el ayuntamiento no podía hacer frente a todo lo que se le exigía, sin ayudas económicas. Al final el sistema reventó, quebró el Ayuntamiento... y entonces el rey montó (1590) su famosa Junta de Ornato y Policía, que venía a quitar otra más de las funciones a los regidores, acaso para su alivio.

Es muy interesante ver cómo en medio del proceso de descomposición de la tradición, un carpintero se obliga a mantener expedito un puente. Si hubiera habido madurez económica, el experimento habría sido muy interesante.

Pero, por el contrario, el conglomerado había venido construyéndose explosivo a lo largo de la segunda mitad del XVI y tenía que reventar: incremento permanente de la población; demanda de más y más necesidades; asunción de responsabilidades que no se podían cumplir sin medios más modernos, no con los tradicionales; arcas municipales que se iban vaciando; incapacidad de pagar con los propios; censos, sisas al final del siglo... y los tapiales de adobe y las calles sin empedrar y los puentes de madera. Clima, técnica y poderes. Es difícil manejar una balanza con más de dos platos.

\section{APÉNDICE DOCUMENTAL}

\section{$N^{\circ} 1 .-$ En el «furor» urbanístico de 1565, Felipe II se interesa por el puente de Toledo}

En 8 de junio de 1565 años, viernes

Estando en el ayuntamiento de la dicha villa los señores corregidor Francisco de Sotomayor y don Lorenzo de Vargas y Diego de Vargas ${ }^{8}$ y el doctor Jerónimo de Pisa y Juan Zapata de Villafuerte y el contador Luis de Peralta y Álvaro de Mena y don Francisco de Coalla.

\footnotetext{
8. [Interlineado]: Diego de Vargas.
} 
En este ayuntamiento se presentó ${ }^{9}$ una provisión de Su Majestad por la cual manda que se trate y confiera sobre lo de la puente Toledana, y se vea la traza y condiciones, y se pregonen y remate la obra. Y con las diligencias que sobre ello se hicieren, se envíe a Consejo. Y con ella fue requerido el señor corregidor por parte de Gregorio Méndez, procurador general de la dicha Villa, el tenor de la cual es este que se sigue:

Don Felipe ${ }^{10}$ por la gracia de Dios Rey de Castilla, de León y de Aragón, de las Dos Sicilias, de Jerusalén, de Navarra, de Granada, de Toledo, de Valencia, de Galicia, de Mallorca, de Sevilla, de Cerdeña, de Córdoba, de Córcega, de Murcia, de Jaén, de los Algarves, de Algeciras, de Gibraltar, de las Islas de Canarias, de las Indias, Islas y Tierra Firme del Mar Océano, duque de Milán, conde de Flandes y de Tirol, etc, a vos, el nuestro corregidor de la villa de Madrid o vuestro lugarteniente en el dicho oficio, y a cada uno de vos, a quién esta nuestra carta fuere mostrada, salud y gracia. Sepádes que por parte de esa dicha villa nos fue hecha relación que en el río de esa dicha villa hay una puente que llaman puente Toledana, la cual está a mucho riesgo y peligro y derribado un petril de ella, que con dificultad puede pasar por ella gentes de a pie ni de a caballo, y es tan angosta que no cabe por ella carro ninguno, por la cual vienen a esta nuestra corte los más bastimentos, a cuya causa mucha parte de ellos dejan de venir en los inviernos, por no poder pasar por el río, y los que pasaren, lo hacen con gran riesgo. Atento a lo cual, nos fue pedido y suplicado diésemos orden como la dicha puente se repare y haga más ancha, como por ella puedan pasar carros, contribuyendo en el dicho reparo y edificio los pueblos y personas que de ella recibieren aprovechamiento, y como la nuestra merced fuese. Lo cual visto por los del nuestro Consejo, se mandó que la obra de la dicha puente se pusiese en pregón y se rematase en la persona que la pusiese en más bajo precio y a más ventaja de la obra. Y porque para hacerse más conveniente y perpetua es necesario hacer las condiciones y orden que ha de guardar el maestro y persona que tomare a su cargo la fábrica de la dicha puente, fue acordado que debíamos mandar dar esta nuestra carta para vos en la dicha razón. Y nos tuvímoslo por bien, por la cual os mandamos que, luego la veáis, hagáis juntar el concejo y Ayuntamiento de esa dicha villa, según lo han de uso y de costumbre. Y en ello confiráis y platiquéis y ordenéis las condiciones que mejor os parecieren que convienen y son necesarias cumplir y guardar por los maestros y personas que hubieren de hacer la dicha puente, para más seguridad fortificación y perpetuidad y menos costa de la obra. La cual haréis poner y pongáis en público pregón en las partes y lugares que viéredes que más conviniere, por término de 20 días, para que parezcan ante vos los maestros y personas que quisieren tomar a su cargo el edificio y fábrica de la dicha puente, conforme a las dichas condiciones en la traza que para ella está hecha, para que la persona que la pusiere y quisiere hacer en más bajo precio y a más provecho, en perpetuidad de la dicha obra, se le rematará, y recibiréis las posturas y bajas que se hicieren, y asignareis día para hacerle remate de la dicha obra recibiendo de las tales

9. [Al margen]: Puente Toledana, provisión.

10. [Al margen]: Puente Toledana. 
personas la seguridad y fianzas que viéredes ser necesario. $Y$ hecho lo suso, antes de hacerse el dicho remate, enviaréis ante los del nuestro Consejo las dichas condiciones que así hiciéredes y las posturas y bajas que se hicieren en el dicho termino, todo signado de escribano, en manera que haga fe, para que lo mandemos ver y proveer lo que convenga. Y no fagades ende al, so pena de la nuestra merced y de 10.000 maravedís para la nuestra Cámara. Dada en la villa de Madrid, a 7 días del mes de junio de 1565 años. El doctor Diego Gasca. El licenciado Villagómez. El licenciado Espinosa. El licenciado Atienza. El licenciado Fuenmayor. Y yo, Juan Fernández de Herrera, secretario de Cámara de Su Majestad, la hice escribir por su mandado, con acuerdo de los del su Consejo. Registrada, Martín de Vergara. Martín de Vergara, por canciller.

Y siendo" obedecida por el dicho señor corregidor con el acatamiento debido, y habiendo conferido y tratado en este ayuntamiento sobre lo contenido en la dicha provisión, dijeron que, teniendo entendido lo que el Consejo manda por su provisión, envió a la ciudad de Segovia y a otras partes a procurar de traer a esta villa a Rodrigo Gil, maestro de cantería, y a otros canteros, los mejores que se hallasen, para que juntamente con los maestro que hay en esta villa, vean la disposición y sitio del río donde se ha de hacer la dicha puente. Y que no se halló al dicho Rodrigo Gil, y que ha venido en su lugar Juan del Valle, vecino de Segovia, maestro de cantería, que con él se junte Juan de Vergara, maestro de cantería, y Juan de Villafuerte, alarife y Luis Sillero, y si se pudiere hacer que Juan Bautista de Toledo se junte con ellos, se procure y si no que los demás se junten y vean lo susodicho, y platiquen y confieran sobre ello. Y con acuerdo y parecer suyo se haga la traza y condiciones que parece que más conviene a la perpetuidad de la obra y a la suntuosidad de ella y al provecho y menos costa de ella. Y para hacerlos juntar y hallarse presentes con ellos a lo susodicho, se nombren a los señores Diego de Vargas y Pedro de Herrera, regidores. Y lo que así se acordare entre ellos, se declare por ante el escribano del Ayuntamiento. Y porque el dicho Juan del Valle, maestro de cantería, ha venido desde la ciudad de Segovia a esta villa a lo susodicho a pedimento de esta dicha Villa, se acordó que se dé por su trabajo de venida y estadía y vuelta a Segovia lo que concertaren con el señor corregidor y los dichos Diego de Vargas y Pedro de Herrera, comisarios y por su libramiento, lo pague Marcos de Almonacid de sobras de rentas, con la cual dicha libranza y carta de pago, le reciban y pasen en cuenta y que para ello se vea la traza y condiciones que están hechas.

\section{No 2.- Ante la inutilidad y los riesgos que supone, se decide derruir la muralla árabe}

En Madrid, viernes 5 de diciembre de 1586 años

En este ayuntamiento entraron los porteros de él y dieron fe que han llamado a los señores regidores que están presentes y a los demás que están en esta villa que por acuerdo del ayuntamiento pasado se mandaron llamar para cierta proposición que el

11. [AI margen]: Puente Toledana. 
señor Corregidor había de hacer en este ayuntamiento sobre lo de las cercas y muralla antigua de esta villa. Y estando juntos, el señor Corregidor dijo que como la Villa tiene entendido de muchos años a esta parte, la muralla antigua de ella que está incorporada con las casas de lo más antiguo y poblado de este lugar con la antigüedad del tiempo y con lo que de ella se ha adelgazado por ensanchar sus sitios los vecinos que han labrado junto a la muralla como por las bóvedas y cuevas que han hecho debajo de ella, y ser mucha parte de ella de terraplén y con las muchas aguas se ha deshecho, está en gran peligro de caerse y con su ruina hacerla muy grande en las casas y moradores de ellas, a los cuales aunque se les ha mandado que la reparen y aseguren, dan diferentes excusas y con mucha dificultad se puede entender la obligación que cada uno tiene al reparo de ella, además de que se tienen por muy costos inútiles los que se pueden hacer para asegurarla presupuesto el estado en que ella está, que es para caerse. Y ha parecido algunos que el mejor remedio sería vaciarla y deshacerla en las partes en que hubiere mayor necesidad y fuere más útil y aprovechar el sitio y materiales que de ella se sacare con el mayor beneficio que ser pueda para esta villa. Y por parecerles buen medio, se le propone porque la señal que ha comenzado a dar por las casas del señor presidente de Castilla y por otras partes, y las continuas lluvias que hay le traen con recelo de que podría suceder algún peligro de los que se temen, y así pide y encarga a los dichos señores traten del remedio por esta orden o por otra con mucha brevedad y cuidado pues es tan conveniente al servicio de Dios nuestro señor y de esta república que gobiernan, porque con esta proposición y las diligencias judiciales que va haciendo con los vecinos de la dicha cerca se descarga.

$Y$ visto por los dichos señores y habiendo tratado y conferido largamente sobre esto, acordaron que los señores Nicolás Suárez, Gregorio de Usátegui, Francisco del Prado y don Luis de Toledo junten todos los papeles y declaraciones que sobre esto han hecho los alarifes, y visiten toda la muralla que hay desde la puerta Cerrada hasta la cava y desde la cava hasta la puerta de Valnadú. Y lleven consigo los alarifes que les pareciere y hagan memoria y relación del estado en que está las dichas murallas y en las partes que tienen o se espera peligro, y de los remedios y reparos que podrían tener, y en cual parte convendría vaciarse y derribarse la muralla por no tener otro remedio ni reparo o por serle a esta Villa útil y beneficioso. Y para hacerse esta elección con fundamento, entiendan de los vecinos qué comodidad y gratificación darían a la Villa si les diese licencia para ocupar el hueco de la dicha muralla, y de todo ello y lo demás que les pareciere traigan una relación por escrito para que en este ayuntamiento se vea y provea con resolución lo que más convenga. Y este acuerdo dieron por respuesta a la proposición de arriba.

\section{No 3.- El Rey constituye la Junta de ornato y policía y lo comunica al Ayuntamiento}

En Madrid, a 7 del mes de mayo de 1590 años, lunes por la mañana

En este ayuntamiento se presentó una cédula de Su Majestad firmada de su real mano, y refrendada de Mateo Vázquez de Leca, su fecha en El Pardo a 4 de mayo en que estamos, del tenor siguiente: 
El Rey.

El licenciado Jiménez Ortiz, del mi Consejo. Sabed que por lo que toca al beneficio y aumento de esta villa de Madrid y para que en ella haya la limpieza, ornato y policía que conviene, me ha parecido diputar personas particulares de quien se tenga satisfacción que lo tratarán y proveerán como convenga con mucho provecho y utilidad, que de estas cosas resultará para la salud y purificación de los aires que con la basura, lodo y polvo en invierno y en verano, y con los muladares que suelen corromper e infeccionar, y para su guarda y custodia en tiempo de pestilencia en lo cual y en la dicha limpieza se suelen gastar y gastan mucha suma de maravedís en cada un año y en cada ocasión de peste, lo cual se excusaría si de una vez se hiciese lo necesario. Y que también resultaría mucha ocasión para tener mejor cuenta y razón con la gente que entra y sale en esta corte así para echar de ella a los vagabundos y holgazanes que suelen hacer tantos hurtos y robos como para no dejar entrar a los que lo fueren. Y poder conocer con más facilidad a los que siendo desterrados de ella quebranten los destierros y para que haya mejor recaudo para los arrendadores de mis rentas reales habiendo puertas ciertas por dónde hayan de entrar y salir las cosas que entran para vender. De todo lo cual Nuestro Señor será muy servido y nacerá la conservación de la salud que tan necesaria es por la ordinaria asistencia de mi real persona en esta villa y de los serenísimos príncipe infante, mis muy caros y amados hijos, y de todo los que residen $y$ van y viene a ella. Y por ser todo esto de general importancia y en que conviene poner mucho cuidado y diligencia así para tratar y conferir todo lo que sobre ello se debe ordenar y proveer como la buena y breve ejecución de lo que se proveyere y ordenare confiamos de vuestra rectitud, diligencia y cuidado. Y acordado de os lo encomendar y cometer, y os mando que juntando con vos a Luis Gaitán de Ayala, de mi Consejo de Hacienda y Corregidor de esta villa de Madrid, y acabado su oficio en su lugar a los Corregidores que por tiempo fueren después de él, y juntamente 2 regidores de esta villa que sean diputados para entender en lo susodicho, nombrados y señalados por el Ayuntamiento con vuestra aprobación todas las veces que fueren necesario y por vuestra orden fueren llamados para las dichas juntas en las cuales tratareis de todo lo susodicho y de lo demás que os pareciere sea útil y necesario para que se consigan los dicho efectos. Y todo ello lo platicad y conferir llamando cuando os pareciere personas expertas y practicas de semejantes materias, y habiéndolos oído de lo que vos, el licenciado Jiménez Ortiz, y el Corregidor que es o adelante fuere, de conformidad, entendiéredes que conviene, me iréis dando cuenta para que habiéndolo visto mande se ponga en ejecución lo que al servicio de Dios y nuestro bien y beneficio de esta villa conviniere. $\mathrm{Y}$ en las cosas que os pareciere tomad el parecer del Ayuntamiento y daréis orden que el dicho Corregidor y diputados lo traten y confieran en él, y lo que a todos o a la mayor parte pareciere, lo traigan a la dicha junta para que habiendo visto lo uno y lo otro se tome la resolución conveniente y se me consulte. $Y$ de las cosas que asimismo os pareciere ser de mucha importancia y consideración daréis noticia al Conde de Barajas, presidente de mi Consejo, vos y el dicho Corregidor o diputados por vuestra ocupación para que la sepa y entienda y porque conviene mucho para el buen progreso, orden y 
ejecución de lo susodicho, y de cada una cosa y parte de ello que no se dé lugar a pleitos con los cuales se embarazaría lo que tanto importa y conviene. Y es mi voluntad y mando que si alguna o algunas personas se sintieren agraviados de lo que se ordenare y mandare ejecutar la dicha junta, ordenéis y mandéis a los que así se agraviaren que den petición en ella del agravio que pretendieren se les hace, declarando muy en particular las causas que para ello tiene. Y en ella se trate y confiera del remedio que podrá haber para deshacer el agravio si lo hubiere tomando sobre ello el mejor medio y arbitrio que se hallare y ofreciere para satisfacción de las partes sin que se dé lugar a más pleito ni dilación, y si no se hallare y fuere necesario que el dicho agravio se determine por tela de juicio, vos, el dicho licenciado Jiménez Ortiz, sustanciaréis los procesos que sobre ello hubiere de haber hasta concluirlos para definitiva sin que de los autos interlocutorios que diéredes se pueda apelar. Y estando conclusos para dar sentencia, se verán y determinarán en ella, juntándose con vos y con el dicho Corregidor sin los diputados, el doctor Pareja de Peralta, alcalde de mi casa y corte, y lo que por la mayor parte de los tres fuere determinado y sentenciado, se guarde y cumpla y ejecute y sea habido por sentencia de revista. Y de lo que así se sentenciare no pueda haber ni haya apelación ni suplicación para ningún otro tribunal y otro remedio ni recurso alguno. Que por la presente doy poder y facultad y plena jurisdicción a todos los jueces y a cada uno de ellos cuan bastante de derecho que requiere para que puedan juzgar y determinar todo lo susodicho y cada una cosa y parte de ello, e inhibo y he por inhibidos del conocimiento y determinación de todos los dichos negocios que por vos y el dicho alcalde y Corregidor fueren determinados, para que por ninguna vía ni forma puedan tratar ni conocer de ellos a mí Consejo y a todos los demás tribunales de estos mis reinos, y a otros cualesquier justicias y jueces de ellos. Y si para el mejor cumplimiento de lo dicho fuere necesario derogar cualesquier leyes de estos reinos las derogo, caso y anulo para sólo este efecto, quedando lo demás en toda su fuerza y vigor. Y porque para que haya cumplido efecto lo que así se ordenare y mandare ejecutar será menester alguna cantidad de dineros, y para ello será necesario hacer algunos repartimientos y buscar arbitrios para sacar el dicho dinero, convendrá que en la dicha junta tratéis y confiráis la orden y traza que se podrá tener en los dichos arbitrios buscando medios cuales que sean de sustancia y de consideración y de la menor graveza que fuere posible, tratándose tan bien sobre ellos cuando os pareciere en el ayuntamiento de esta villa. Y llevado a la junta su parecer en ella, se tomará la resolución que más convenga, la cual me consultaréis para que habiéndola visto y entendido ordene y mande lo que se hubiere de hacer sobre ello, y se ejecute lo que yo mandare y todos los autos asi de los repartimientos y otros arbitrios y arrendamientos de ellos, judiciales y extrajudiciales que se hubieren de hacer en la dicha junta. Es mi voluntad y mando que se hagan y pasen ante Francisco Martínez, escribano del regimiento de esta villa, y para que haya cuenta y razón de todo lo que procediere de los dichos repartimientos y arbitrios mando que como se fueren cobrando se entregue luego en poder del depositario general de esta villa, el cual depósito se haga por ante el dicho Francisco Martínez y por ante Hernando Delgadillo, al cual nombro y señalo por contador de las dichas obras, el cual y el dicho Francisco Martínez tengan cada uno su libro donde se asiente lo que así se fuere depo- 
sitando por cada uno de por sí para que por los dichos libros se le pueda hacer cargo al dicho depositario cuando se le quisieren tomar cuenta. Y lo que se fuere gastando en las dichas obras y para ellas se tomare, se haya de pagar y pague por libranzas mandadas despachar en la dicha junta firmadas de vos el licenciado Jiménez Ortiz y del dicho Corregidor y uno de los dichos diputados, de las cuales tomen la razón el dicho Francisco Martínez y el dicho contador, y las asienten en otros de la razón que para ello mando tengan, y en las dichas libranzas asienten como está tomada la razón en sus libros, las cuales firmadas como dicho es y tomada la razón cumpla el depositario y no de otra manera. Y mando y encargo a los dichos dos regidores diputados tengan gran cuenta y razón en visitar y ver las dichas obras y acudan a la buena ejecución de ellas por la orden y forma que les diéredes, de manera que se hagan con la brevedad, bondad y perfección que conviene, para todo lo cual y cada una cosa y parte de ello, os doy poder y comisión en forma cuan bastante de derecho se requiere y para todo lo a ello anejo y dependiente y concerniente. $Y$ mando al presidente y a los del mi Consejo y alcalde mi casa y corte os den el favor y ayuda necesarios para la ejecución de lo susodicho y que en ello no os pongan estorbo ni embarazo alguno. Otrosí, mando a todos los alguaciles de mi Casa y Corte y de esta villa de Madrid que ejecuten las órdenes y mandamientos que en razón de los susodicho les diéredes y mandáredes cumplir so las penas que por vos les fueren puestas, las cuales ejecutaréis en los que rebeldes inobedientes fueren. Dada en El Pardo a 4 de mayo de 1590 años. Yo, el Rey. Por mandado del Rey nuestro señor, Mateo Vázquez de Leca. Y al cabo de la postrera plana de la dicha comisión está rubricado de la rúbrica del señor Conde de Barajas, presidente del Consejo de Su Majestad.

Concuerda con el original de donde se sacó, Francisco Martínez (rubricado y firmado).

Y vista y leída la dicha cédula real y entendida por la dicha villa y platicado y conferido sobre la elección de los dos comisarios regidores, nombraron por comisarios como Su Majestad por su real cédula manda, a los señores don Pedro Zapata y Gabriel de Galarza, regidores de esta villa, a los cuales dieron poder y comisión en forma como es necesario y en tal caso se requiere, para que desde aquí el primero ayuntamiento del mes de mayo del año de noventa y uno, usen y ejerzan el dicho oficio, y como tales comisarios hagan todo lo a la dicha comisión anejo y dependiente conforme a la dicha cédula real de Su Majestad.

$N^{\circ}$ 4.- Ante la sequia, se pide licencia al Consejo para hacer una procesión (porque el Consejo ha de dar licencia para pagar los gastos que se generen) y se decide hacerla el sábado 8 de mayo de 1593. En las mismas fechas, en 1594, ocurre otro tanto

En Madrid, a 5 días del mes de mayo de 1593 años, miércoles por la mañana.

Acordóse que el señor Melchor de Matute hable al señor presidente en nombre de esta Villa y le represente la necesidad que hay de agua y le suplique dé licencia para que se hagan procesiones de rogativas. 
A 7 días del mes de mayo de 1593 años.

En este ayuntamiento, habiendo dicho en él Francisco Martínez, su secretario, que el señor Jiménez Ortiz le había dicho que ya el Consejo había dado licencia para que Madrid hiciese todas las procesiones de rogativas que quisiere por el agua y entendido por la dicha Villa, se acordó que se hagan tres procesiones generales en que se halle toda la Villa, que la primera vaya a Nuestra Señora de la Merced y sea mañana sábado, y la segunda, el lunes, a Loreto, y la tercera, el martes, a la Victoria. Y el señor Gregorio de Paz hable al vicario para que se ordene y que sean muy generales, saliendo de la iglesia de Santa María, y en cada monasterio se diga una misa cantada y se acabe allí la procesión y que se llame a todos los señores regidores que se hallen en ellas, so pena de 2 ducados de pena a cada uno aplicada para el Hospital General, en la cual pena, desde luego, se da por condenados, constando por certificación del secretario que ha faltado de la dicha procesión, sin otra diligencia ni averiguación alguna, no estando impedido con justo impedimento.

En Madrid, a 11 días del mes de mayo de 1593 años, miércoles por la mañana.

Acordóse que el señor Gregorio de Paz hable al vicario de parte de esta Villa y concierte con él la procesión que tiene acordado se haga para sacar a Nuestra Señora de la Antigua de San Nicolás, y el día y hora que será y, avisado, se llamen los señores regidores que se hallen en ella.

En este ayuntamiento se acordó que, atento las necesidades que hay de los temporales, se pida al Consejo se dé licencia para que se saque Nuestra Señora de Atocha en procesión, y se traiga a Santa María, adonde esté tres días, y de allí se vuelva a su casa por la parte que se señalare y que en ello se gaste todo lo que fuere necesario, como se hizo otra vez que se sacó de cera, y sustentar los frailes y darle un manto. Y se suplique a los regidores se hallen en la procesión, en recibir la dicha imagen y volverla y los señores don Luis de Toledo y Leandro Hurtado sean comisarios de este negocio y den la orden que fuere necesaria que conviniere, así en sacrificios y misas como en los demás gastos referidos, y señalen el día para ello y se pida licencia al Consejo para el gasto de la sisa o sobras de rentas.

En Madrid, a 14 días del mes de mayo de 1593 años.

Acordóse que, atento que esta Villa tiene licencia del Consejo para traer en procesión la Santísima imagen de Nuestra Señora de Atocha, trayéndola desde su bendita casa a Santa María por la rogativa del agua, se haga la dicha procesión el domingo por la tarde, a las 6, en la cual se ha de hallar esta Villa por Villa, y a cada uno se le dé su hacha en la dicha procesión en la forma que se llevó otra vez que se trajo la dicha santa imagen, y venga toda la calle derecha por la plaza y puerta de Guadalajara y platería derecha hasta Santa María, adonde ha de quedar tres días. Y se pregone que todos rieguen y barran y cuelguen sus pertenencias, so pena de 600 maravedís, repartidos por tercias partes y esta pena se ejecute. Y el señor don Diego de Olivares haga regar con las cubetas todo el campo, desde el monasterio hasta la puerta de la villa, y se haga en este acompañamiento. Y en lo demás se guarde la orden que se tuvo el año de ochenta 
y ocho y en los demás años que se ha traído la dicha imagen a esta villa y se le dé un vestido a Nuestra Señora en la forma que se le dio otra vez y todo se libre y pague de sobras de rentas conforme al decreto del Consejo.

En Madrid, a 25 días del mes de abril de 1594 años, miércoles por la mañana

En este ayuntamiento se acordó que se empiecen a hacer algunas procesiones de rogativas, suplicando a Nuestro Señor por los temporales, atento la falta grande de agua que hay para los frutos de la tierra y que en algunos lugares se empiecen a hacer procesiones por ello y se hable una palabra al señor Presidente para que Su Señoría dé licencia para ello y el señor don Pedro de Vozmediano lo haga.

En Madrid, lunes por la tarde, 2 días de mayo 1594 años

En este ayuntamiento se acordó que, atento la necesidad que hay de agua para los temporales por estar el tiempo tan adelante que se dilata y es bien que se suplique a Nuestro Señor se sirva de darla como es menester para los temporales, haciendo procesiones y oraciones por ello y que, atento que esta Villa tiene licencia del señor Presidente del Real Consejo para gastar lo necesario en ellas, se acuerda que se haga el jueves por la tarde una procesión general que salga de Nuestra Señora de Loreto, trayéndola desde su Santa Casa a la iglesia de Santa María de esta villa y venga por la calle de Atocha derecha y entre por la iglesia de San Sebastián y allí se haga oración y baje por la plaza y platería a la dicha iglesia y donde esté tres días y los señores comisarios de la cera del Santísimo Sacramento provean de la que fuere necesaria, así de hachas como de velas, para que se alumbre la dicha Santa Imagen. Y la villa lleve hachas blancas y si éstas no se pudieren hallar, lleven velas de a libra y media o dos libras como pareciere a los dichos señores comisarios. Y se hable al señor vicario por los señores Diego de Chaves y Diego de Henao para que haga salir todas las órdenes con sus cruces, como salen la fiesta del Santísimo Sacramento, y todas las cofradías con sus hachas y pendones, como suelen, de suerte que se haga una procesión general solemnísima y el señor don Pedro de Vozmediano prevenga para esta procesión la capilla real de Su Majestad y vayan los ministriles en ella.

Que los señores Felipe de Vallejo y Juan Fernández hagan colgar la dicha iglesia de Santa María y el mayordomo de propios provea de ramilletes y respadaña con intervención de los dichos señores comisarios. Y se lleve el palio con que se lleva el Santísimo Sacramento y lleven clérigos las varas del palio y las andas y hachas, alumbrando la imagen. Y el señor teniente haga pregonar cuelguen y limpien las calles por do ha de venir la procesión y alcen los oficios y lo que se gastare en todo se pague por libranzas de los señores comisarios y el señor Corregidor y su teniente conforme a la licencia.

En Madrid, a 4 de mayo de 1594 años, miércoles por la mañana

Acordóse que, para el día que está señalado, se haga la procesión general, sacando en ella a Nuestra Señora de Loreto, como está acordado, y que si el día no hiciere para hacerla, pase al domingo. 
Este día por la tarde (6 de mayo 1594)

Que se pase en cuenta a Pedro de la Carrera 20 reales por otros tantos que pagó a un correo que fue a llevar una carta a García de Loaysa, limosnero mayor, para que diese licencia a la capilla sirviese en la procesión general que ha de salir con Nuestra Señora de Loreto por la rogativa del agua y 14 reales que pagó a otro correo que fue a llevar una carta a don Cristóbal de Mora del señor licenciado Bohórquez para que dé los foliones para servir la fiesta del Santísimo Sacramento, que por todos son 34 reales y se le reciban y pasen en cuenta con este acuerdo, tomando la razón los contadores de esta villa.

En Madrid, a 9 de mayo de 1594 años, lunes por la mañana

En este ayuntamiento se trató de la desorden que hay en las procesiones que esta villa hace con los clérigos del cabildo y que siempre de ordinario hay un gran escándalo que parece mal al pueblo y que no acuden a ellas sus vicarios y ésta es la causa del dicho alboroto. Para remedio de lo cual, se acordó que los señores don Diego de Olivares y Diego de Henao hablen al señor Cardenal de Toledo y le supliquen de parte de esta villa para el remedio de ello y que mande al dicho clero acudan a todas las procesiones votivas que esta villa hiciere y que vayan en ellas en la forma que suelen y acostumbran ir en las demás procesiones que ellos de obligación tienen y tienen votado. Y no remediando en esto el dicho Cardenal lo que convinieren, acudan al señor Presidente y al Consejo para que lo remedie para que no haya alguna deficiencia en la procesión que viene.

En Madrid, a 11 días del mes de mayo de 1594 años, miércoles por la mañana

Que mañana jueves por la mañana, digo, por la tarde, se vuelva a su casa la bendita imagen de Loreto en procesión por las propias calles por donde vino, si no se ordenare otra cosa y los señores comisarios hablen al señor vicario para que haga prevenir las órdenes y clerecía y cofradías y todo lo demás necesario.

En Madrid, a 12 días del mes de mayo de 1594 años, jueves por la mañana

En este ayuntamiento se acordó que, atento que la bendita imagen de Nuestra Señora de Loreto se ha traído en procesión en rogativa por el agua y que para hacer algunas fiestas en esta procesión, tiene licencia del Consejo de Su majestad y pagarlos de sobras de rentas y que el año pasado de noventa y tres cuando se trajo la bendita imagen de Atocha, se le dio un vestido que costó más de 300 ducados y que por evitar tanto gasto en esta ocasión, como se hizo el dicho año pasado, así en el dicho vestido como en lo demás, se acordó que se den la dicha imagen de Loreto un manto de la forma que pareciere a los señores comisarios que cueste 500 reales y se pague de las dichas sobras de rentas en virtud de la dicha licencia de ella. 
En Madrid, a 25 de mayo de 1594 años, miércoles, por la mañana

Que se dé a los trompetas y atabales que sirvieron en la procesión de Loreto 6 escudos en oro y otro tanto a los músicos por los días que sirvieron en tañer [ilegible] de la imagen de Nuestra Señora.

Año de 1561

Primavera y verano excesivamente calurosos:

2-VI-1561: «El señor Corregidor dijo que estando en su posada vinieron a él algunos de los señores regidores, y le dijeron que por la gran calor que hacía que sería bien que entrasen en ayuntamiento temprano, y que él dijo que se fuese luego a llamar a los otros señores regidores, y señaladamente a los señores licenciado Saavedra y Pedro de Herrera, y que luego mandó ir a ello a Francisco Díaz, portero, el cual vino a decir como los había llamado, y que asimismo, muy poco antes de la hora acostumbrada por las razones susodichas se comenzó el ayuntamiento».

Repercusiones declaradas: nadie se ha querido hacer cargo del abastecimiento de sebo y aceite para la ciudad; males en los olivos; subidas de los precios.

11-VII-1561: «El señor Diego de Vargas [regidor] dijo que se han hecho diligencias para que haya obligado de candelas este año, y también los señores alcaldes de Corte las han hecho, y no han hallado quien se obligue por la grande esterilidad que hay y falta de sebo [...] [Que el regidor Pedro de Herrera y el Corregidor], tenga cuenta con el abastecimiento de la candelería y de enviar a comprar sebo a donde quiera que hubiere, y hacerlo traer a esta Villa, y tomar candelero o candeleros que hagan las dichas velas, y concertar el precio de que se les haya de dar por la hechura de ellas [...] Y que si no se diese la dicha comisión [léase: autorización por el Consejo Real] y se diese orden cómo se abasteciese, como se hizo el año pasado, la república padecería como al presente padece, que ha muchos días que no se pesa libra de velas y a muy excesivo precio».

8-VIII-1561: «El señor Álvaro de Mena [regidor] dijo que porque ha oído que al tiempo que se obligó [el obligado del aceite] valía el aceite a 13 y a 14 reales la arroba y ahora a ha oído decir que vale el arroba 22 reales, a causa de la esterilidad del tiempo, porque dicen que los olivares no tienen aceituna, ni hay manteca ni sebo».

En ayuntamiento (8-VIII-1561) se discute sobre si se autoriza o no la subida del precio del sebo y sus derivados (especialmente las candelas) y a raíz de ello, siguen apareciendo las sensaciones sobre el problema, como expresa un regidor: «porque la falta que ha habido estos días pasados ha sido mucha y padece el pueblo mucho más en que haya falta de aceite que no en que se le suba el dicho precio».

Año de 1562

Se espera riadas otoñales.

«En este ayuntamiento (7-IX-1562) se acordó que, por cuanto está cometido a los señores Álvaro de Luján y Pedro Fernández de Ludeña hacer tres estacadas en el río de Jarama, para que el dicho río no se acabe de llevar el Soto de la Sopeña, que es de esta Villa, por no haberse hecho hasta ahora las dichas estacadas, y si ahora no se hiciesen, se lo acabaría de llevar. Que se comete al señor Pedro de Herrera para que vaya, juntamente con 
los dichos señores, a la dicha ribera y haga tomar orden con maestros que sepan hacer las dichas estacadas, para que se hagan con la brevedad posible antes que vengan las aguas. $Y$ hable a los principales herederos de Vaciamadrid para que, pues les viene utilidad y provecho, pongan alguna persona que esté allí por sobrestante, y sus renteros u otras personas».

Y las crecidas llegaron:

«En este ayuntamiento se cometió (28-IX-1562) al señor Diego de Vargas que haga nivelar el agua de [la fuente de] Leganitos, para ver dónde puede venir».

$\mathrm{Y}$ tocaron la estructura del puente de Viveros (véase texto del artículo, 16-X1562). No hubo tiempo de arreglar todo y se echaron piedras en los ríos para hacer vados (véase texto, 4-I-1563). También se denuncia que la puente Segoviana se hunde, aunque no sabemos si es por las riadas (vésae texto, 20-III-1563). Se dan por finalizadas las obras en 4-VIII-1563. Se lo lleva una riada el 6-XII-1563.

Año de 1563

Invierno (1562-63) seco y bonancible. Primavera de 1563, muy lluviosa. Poca cosecha. Invierno de 1563 lluvioso.

Se aprovecha para pavimentar las calles (véase texto, 27-II-1563). Se arruinan las cosechas de cereal (véase texto 2-VI-1563). Poca cosecha de cereal (13-XI-1564). La riada se lleva el puente de Segovia (6-XII-1563). Se denuncia que el puente de Viveros se viene abajo (12-VII-1564).

Año de 1564

Verano de 1564, seco.

Se «quemó una parte del monte, junto a los labrados de Navalacarrera [sesmo de Vallecas], y porque si el ganado entrase en ello el tallo que ahora echa se le comerian...» $(10-1 \mathrm{~V}-1565)$.

Año de 1565

Invierno de 1565: Riadas. Muy lluvioso.

E1 3-I-1565 se comunica que el río se ha llevado el puente de Viveros. Se reparará por vía de urgencia con sobras de rentas del encabezamiento. «Hoyos» en el Puente de Segovia (3-I-1565). La pontezuela del Pozacho necesita reparación (3-I-1565). Se caen las tapias de la Casa del Pescado (3-I-1565). Se pide ayuda al Consejo Real para rehacer los puentes de Toledo y Segovia (3-I-1565). El 15-1-1565 se pagan los reparos hechos en el de Toledo.

Año de 1566

Muy seco.

El 26 de febrero de 1567, en el ayuntamiento se dice que «el tiempo está muy adelante para plantar cualquiera género de árboles, y que los más están ya echados y con flor, y que además de esto que la tierra está muy seca y no dispuesta para poder plantar, de cuya causa les parece que todo lo que se plantase se perdería». 
Año de 1567

Primer medio año seco. Invierno lluvioso. Se saca trigo del alholí.

Se decide cambiar el curso de los ríos y arroyos:

«En este ayuntamiento [16-VI-1567] se acordó que se vaya a ver y nivelar de las partes y lugares de donde se podrá traer agua al río de esta villa, que es de Jarama y de los arroyos de Guadalix y Porquerizas y Peñalara y el río del Pavear».

En diciembre las riadas causan desperfectos en los puentes del Jarama y Viveros. Se decide paralizar las obras municipales: «[Los alarifes, 17-XII-1567] dijeron que todas las dichas obras de albañilería y mampostería que la Villa trae conviene para la perpetuidad y seguridad de ellas cesen hasta en fin de febrero»

Se empieza a sacar trigo de las trojes. El primero, el picado por gorgojo.

Año de 1568

Esterilidad. Inundaciones invernales.

«En este ayuntamiento [23-II-1568] se otorgó petición para el Consejo Real para que la Villa de sobras de rentas pueda dar de limosna al monasterio de Nuestra Señora de Atocha 50 ducados para trigo atento la grande esterilidad del tiempo, y se comete al señor Alonso de Zárate para que dé la petición y haga en ello las demás diligencias necesarias».

Los de Paracuellos construyen una presa ilegal (18-III-1568) para luchar contra la sequía. En mayo, el río se lleva las riberas en Arganda y la barca. En diciembre los barqueros siguen quejándose.

Año de 1569

Invierno 1568-69: inundaciones.

Reparaciones en el pontón que va a Pozuelo (12-I-1569).

Año de 1570

\section{Esterilidad.}

Los vecinos de Fuencarral piden aplazamiento del pago del trigo que han de llevar a Madrid «atento la esterilidad del año» (19-I-1571).

Año de 1572

Riadas. Excelente cosecha de pan.

El Jarama se lleva la tajada de la barca. (13-II-1572).

Se ordena una baja notable del precio pan de Villa - para vaciar las trojes- «atento el buen año, y se pregone» (31-X-1572).

Año de 1574

Riadas en primavera y en otoño.

El Jarama se lleva la tajada de la barca. (9-III-1574).

El puente de Viveros es dañado de nuevo por la riada de 3 de septiembre (sesión municipal de 16-IX-1574). 
Año de 1575

Riadas en invierno. Pésima cosecha.

El puente de Segovia, afectado (9-II-1575).

Se saca trigo del alholí para préstamo de sembradura, hasta 1.300 fanegas (16-XI1575), a Fuencarral en concreto, 300 (21-XI-1575)

Año de 1576

Sequía en invierno. Pésima cosecha. Lluvias torrenciales en otoño.

Se preparan procesiones (29-II-1576).

Se sacan otras 1.000 fanegas de sembradura en préstamo (8-X-1576).

El Corregidor aplaza la visita a la Tierra de Madrid hasta que se «asiente el tiemро» $(22-X-1576)$

Año de 1577

Pésima cosecha. Mucho frío en otoño.

El ayuntamiento opta por comprar 30.000 fanegas de trigo para el alholí (4-II1577). Se prohíbe rastrojar, para que los ganados tengan algún alimento (12-VI-1577). Se permite encender los braseros municipales el 23-X-1577, una semana antes de lo habitual. Se ordenan las compras de carbón.

Año de 1578

Sequía. Mucho calor en primavera. Pésima cosecha. Escasez de carne.

El Manzanares no tiene agua y no se puede moler. Se lleva el trigo al Jarama (9-V-1578). Hace tanto calor que se insta al Corregidor que postponga la visita de la Tierra (26-V-1578). Todo el cereal en grano o molturado que se meta en Madrid, estará horro de alcabala (9-VII-1578). Los obligados de las carnicerías piden una subida del precio de la carne, por las carencias que hay (10-I-1579): «La pérdida de los obligados es mucha y muy notoria y la falta de las carnes es grande por la esterilidad de los tiempos».

Año de 1579

Riadas y lluvias otoñales.

Se ordena la demolición de unas almenas de la muralla que van a ceder por las lluvias (14-IX-1579). El Jarama vuelve a llevarse la tajada (13-XI-1579).

Año de 1580

Buen tiempo en primavera. Sequía en verano.

Debido a la bonanza del tiempo en la primavera de 1580, que «habiéndose sembrado por mandado de Su Majestad un pedazo de tierra junto a las dehesillas de Torrejoncillo, ribera del río Jarama [...] ahora lo sembrado está muy bueno y que algunos ganados le entran a pacer y no es justo se coma» (5-III-1580). 
Las fuentes de Madrid no dan agua y la ciudad no tiene dinero para repararlas. Se decide hacer memoriales al rey y al Consejo de Hacienda (8-VII-1580):

«El pilar del camino de Alcalá, que es una cosa tan necesaria, está seco y las fuentes de él no corren, ni las dos fuentes que están cerca de él menos y que es cosa muy importante [...] esta Villa dé orden cómo se remedien y reparen porque a causa de no haberse hecho [en otras ocasiones] han venido a perderse y secarse, de tal manera que no corren las del dicho pilar ni las demás cerca de él y las demás se van secando y perdiendo. Y lo mismo ha sucedido en las de Leganitos y La Priora y fuentes de El Peral y Lavapiés, y con que se han hecho otros acuerdos y dado memoriales a Su Majestad y otros señores ministros de su Consejo de Hacienda, a quien se ha remitido, hasta ahora no se ha hecho ninguna diligencia sobre este particular. $Y$ esta Villa ha venido ya a tal estado que aunque quiere repararlo no tiene de qué de ninguna forma por estar tan endeudada y empeñada....»

Año de 1581

Lluvias en enero (?). Sequía en primavera. Mucho calor. Sequía al principio del verano, seguida de grandes tormentas. Riadas en otoño.

Se suspenden el empedrado de la calle de Atocha. Se reanudan «pues que las aguas y rigor del tiempo, porque se suspendió, han cesado» (18-II-1581). Aparecen goteras en el alholí de la Villa (1-II-1581). «En este ayuntamiento el señor Velázquez de la Canal propuso y dijo ${ }^{12}$ la necesidad que al presente hay de agua y la falta que hace cada día, de que sería necesario que se hiciesen procesiones para ello y para la salud» (17-IV-1581). Se hizo una el 20 de abril de 1581 . Se espera una pésima cosecha (13-V1581). El ayuntamiento tiene prisa por terminar una obra que les quita el sol de la sala de reuniones (21-VI-1581). Que se barran y limpien las calles principales en verano (7VII-1581). Primeras solicitudes de aplazamiento de pagos de arrendamientos de tierras por la sequía (19-VII-1581). «Para que las avenidas del agua no hagan el daño que han comenzado» (11-VIII-1581). Por vez primera hallamos en las discusiones de Cortes que se usa el clima como causante de los males del campo y no los impuestos (20IX-1581). Se ha hundido la barca de Arganda (16-X-1581). «Turbión» (aguacero con viento fuerte, intensísimo y muy breve) en Madrid en septiembre que arrasa la fuente del Prado (noticia en 29-XI-1581). Se decide repararla y llevarla cerca del monasterio de Atocha. A 14 de enero de 1587 se acuerda que se i»reedifique el pilar del prado al paso del camino de Alcalá que se llevó el turbión el año de ochenta y uno»...!

Año de 1582

Grandes lluvias en enero. Primavera muy bonancible. Verano muy duro.

«Por el buen suceso del tiempo, este inconveniente de las moliendas ha cesado» (24-IV-1582). «Rigor y carestía del tiempo» (3-VIII-1582): se va a La Mancha a comprar cien mil fanegas.

12. [A1 margen]: Procesiones por el agua. 
Año de 1583

Buenas cosechas.

Se suspenden los transportes de grano desde La Mancha (4-VII-1583).

Año de 1584

Sequía. Malas cosechas.

No llega pan a Madrid (27-IV-1584). Se saca a la Virgen de Valverde en romería (27-IV-1584). Esterilidad en verano (3-VIII-1584). Gravedad de la carestía (11-VIII1584).

Año de 1585

Excelente cosecha.

«Este año es tan abundoso [de pan] que en cualquier parte se puede hacer [provisión] sin daño de las repúblicas y pueblos donde hubiere pósito» (2-IX-1585).

Año de 1586

Riada del Jarama. Inundaciones en Madrid.

La muralla se viene abajo.

Año de 1587

Se declara que se lleva tres años excelentes. Se espera (15 y 19-VI-1587) excelente cosecha. Muchas aguas en otoño.

20-V-1587: «En consideración de que Nuestro Señor ha sido servido de dar tres años continuos con éste de tanta abundancia de pan que se espera que lo nuevo que se ha de coger ha de valer a muy notable y bajo precio, y porque es muy extraordinario la merced que Nuestro Señor ha hecho de dar tres años de fertilidad, según la orden natural de los tiempos se puede tener recelo que faltará esta abundancia en los primeros años venideros...) será bueno comprar 200.000 fanegas y reconstruir el alholí.

Por lluvias se han de paralizar obras de reconstrucción del embarcadero del Jarama (23-IX-1587). Se caen paredones dentro de la ciudad (16-XI-1587). Los comisarios que han ido a comprar el trigo soportan que «el tiempo es muy áspero de aguas y lodos y malos caminos y no han de estar de asiento en ningún lugar, sino por ventas y mesones» $(20-X I-1587)$.

Año de 1588

Hay suficientes reservas de grano. Año fértil (5-IV-1588). Se consideran «buenos» los cuatro años anteriores. Sequía en invierno.

«la falta que ha habido de agua el invierno pasado que ha muchos años que no ha habido tanta〉 (5-V-1589)

«...y la cantidad con que esta villa se halla de grano y lo que se puede esperar después y haber pasado cuatro años buenos» (11-VII-1588). 
Año de 1589

Falta de pan por la sequía del invierno de 1588 (22-1-1589). Graves heladas invernales (1-II-1589). El río baja sin agua (21-III-1589). Problemas en la molienda (21-III1589). Peticiones para hacer rogativas (1 y 17-IV-1589). Previsión de sequía estival (5V-1589), que se confirma (5-VII-1589). Pésima cosecha. Peste en Barcelona y mucho frío en Madrid (30-X-1589). Grandes heladas «de más de un día» (15-XII-1589). El mayordomo del pósito pide aumento de sueldo porque ha trabajado mucho, «con la mucha falta de pan y con las muchas compras que se han hecho» (26-I-1590).

Año de 1590

Invierno próspero de aguas «se espere que ha de haber buena cosecha de trigo y cebada» (23-II-1590). Se renuevan las existencias del alholí y se necesita más personal para registrar las compras y ventas (28-IV-1590). Se constituye la regia Junta de Ornato (4-V-1590): el ayuntamiento pierde otra parte de sus competencias. El Jarama baja con «mucha furia». De nuevo, preparativos para procesiones «por la serenidad y bonanza del tiempo» (8-VI-1590). Mala cosecha: «la cosecha del pan de este presente año no están buena como se esperaba generalmente hablando»; se decide hacer compras de trigo como se «acostumbra proveer en los años de mediana cosecha» (20-VII-1590). Lluvias de otoño «estando como se está al fin del mes de septiembre y comenzado a embarazar los caminos con las lluvias que han caído siendo el año como es antes estéril que abundoso» (17-IX-1590). El trigo que se compró fue tanto que no cupo en el alholí y se entrojó en monasterios, etc. (según refieren en 23-X-1591). Daños en la puente Segoviana y en la barca de Arganda (19, 30-I-1590, etc.). Daños en el puente de Toledo (7-II-1590). Se cae una parte del puente de Viveros (19-X-1590).

Año de 1591

Sin problemas. Nuevas reparaciones en la barca de Arganda (19-VIII-1591). Acaso otoño caluroso, «por ser el tiempo ya tan caluroso y haberlo recibido [el trigo para el alholí] tan mojado» $(23-\mathrm{X}-1591)$.

Año de 1592

Langosta (8-IV-1592). Graves problemas para pagar los costes de la lucha contra el insecto (30-IV-1592). Mala cosecha: ante el capítulo de los franciscanos en Madrid, temen que no haya trigo suficiente con qué alimentarlos «atento lá poca cosecha de este año» (13-XI-1592). Reparaciones en el puente de Viveros (30-X-1592).

Año de 1593

Por vez primera se trata en el ayuntamiento que la provisión de cereal se haga por medio de un asiento con Antonio Grafión. Inundaciones en primavera (12-III-1593). Sequía en primavera: se empieza a hacer procesiones $(5,7,11$ y 14-V-1593). El río se lleva la barca de Arganda y daña a la de Madrid y a la de Vaciamadrid (6-X-1593, 24- 
XI-1593). Fuertes lluvias dentro en la Villa (19-IX-14593). Se busca amarre de refugio para la barca de Vaciamadrid (24-XI-1593).

Año de 1594

Continúa la sequía. Preparativos de rogativas desde 25-IV-1594; nuevamente en agosto. Se saca la barca del río antes de que se la lleve una riada (14-X-1594). Reparaciones en Viveros (30-VI-1594).

Año de 1595

En invierno, la barca está totalmente destruida y hay que hacer una nueva (24-I1595). Sigue la sequía. Rogativas en enero a San Sebastián y a San Marcos en abril (24-X-1595). No se puede pasar por los caminos hacia El Pardo (11-II-1595).

Año de 1597

«Avenidas y crecientes» dentro de Madrid (13-I-1597).

Año de 1598

Sequía en primavera. Rogativas (mayo). Reparos en Viveros (6-VII-1598). 